OPEN ACCESS

Edited by:

Christian Marcelo Ibáñez, Andres Bello University, Chile

Reviewed by:

Giambattista Bello,

Retired, Mola di Bari, Italy

Joao Braullio Luna Sales,

Federal University of Pará, Brazil

*Correspondence:

Fernando Á. Fernández-Álvarez f.a.fernandez.alvarez@gmail.com

TORCID:

Fernando Á. Fernández-Álvarez orcid.org/0000-0002-8679-7377

Pilar Sánchez orcid.org/0000-0002-3776-7358 Roger Villanueva orcid.org/0000-0001-8122-3449

Specialty section:

This article was submitted to Marine Evolutionary Biology, Biogeography and Species Diversity, a section of the journal

Frontiers in Marine Science

Received: 22 November 2020 Accepted: 22 December 2020

Published: 20 January 2021

Citation:

Fernández-Álvarez FÁ, Sánchez P and Villanueva $R$ (2021) Morphological and Molecular Assessments of Bobtail Squids (Cephalopoda: Sepiolidae)

Reveal a Hidden History of Biodiversity.

Front. Mar. Sci. 7:632261 doi: 10.3389/fmars.2020.632261

\section{Morphological and Molecular Assessments of Bobtail Squids (Cephalopoda: Sepiolidae) Reveal a Hidden History of Biodiversity}

\author{
Fernando Á. Fernández-Álvarez ${ }^{1,2 * t}$, Pilar Sánchez ${ }^{2 \dagger}$ and Roger Villanueva ${ }^{2 \dagger}$ \\ ${ }^{1}$ Ryan Institute and School of Natural Sciences, National University of Ireland Galway, Galway, Ireland, ${ }^{2}$ Institut de Ciències \\ del Mar (CSIC), Barcelona, Spain
}

Molecular species delimitation assists taxonomic decisions for challenging species, like cryptic species complexes. Bobtail squids (Family Sepiolidae Leach, 1817) are a very diverse group of benthic and nektonic small to medium size cephalopods with many taxonomic questions to solve. In this study we provided new sequence data for 12 out 17 Mediterranean bobtail squid species including all the genera present in the area. Other relevant species from other parts of the world were used as comparison. The combined use of several molecular species delimitation methods consistently showed a picture of hidden biodiversity within this family which hinders the use of molecular data isolated from morphological characters. On the one hand, those methods provided contrasting results for the number of recognized species of some morphologically well-defined species. We suggest this can be an effect of recent speciation phenomena followed by an intense morphological drift. On the other hand, cryptic biodiversity was detected among members of several monophyletic clades assigned to the same nominal species, pointing to recent speciation phenomena without a parallel morphological evolution. Although Mediterranean bobtail diversity has been extensively studied for more than a century, a new species of Stoloteuthis Verrill (1881) was discovered and described here, both using molecular and morphological methods. This new research stresses the necessity of combined morphological and molecular studies to correctly assess cephalopod diversity. urn:Isid:zoobank.org:act:57AFBB38-18EA-4F80-B1D4-73519C12694F.

Keywords: Mollusca, cryptic species, molecular species delimitation, systematics, taxonomy, new species

\section{INTRODUCTION}

The use of molecular species delimitation methods is widespread in modern systematics and taxonomic research. Methods such as the Automatic Barcode Gap Discovery (ABGD, Puillandre et al., 2012), the statistical parsimony networks (e.g., Pons et al., 2006), the Bayesian Poisson Tree Processes model (bPTP, Zhang et al., 2013) and the Generalized Mixed Yule Coalescent approach (Fujisawa and Barraclough, 2013) assist in taking taxonomic decisions for challenging species, like cryptic species complexes (e.g., Fernández-Âlvarez et al., 2020) or other morphologically challenging organisms. Molecular species identification methods, such DNA barcoding (Hebert et al., 2003), provide tools for identification of challenging organisms, such as undescribed 
ontogenetic stages of known species (e.g., Fernández-Álvarez et al., 2017, Olmos-Pérez et al., 2018a,b; Villanueva et al., 2020).

The family Sepiolidae Leach, 1817, commonly known as bobtail squids, is a very diverse group of benthic and nektonic small to medium size cephalopods. In recent years, the taxonomy and systematics of the family has been dynamic, including a few molecular phylogenetic studies (e.g., Groenenberg et al., 2009; Sanchez et al., 2019), major systematics reviews (Bello, $2019,2020)$ and the description of a relatively large number of new species (e.g., de Heij and Goud, 2010; Kubodera and Okutani, 2011; Sanchez et al., 2019). In the last decade, new species have been even discovered in the Mediterranean Sea (Bello, 2013; Bello and Salman, 2015), where bobtail squid diversity has been extensively studied for more than a century (Bello, 2015, 2019). The closure of the Strait of Gibraltar is an historical process that may explain the contemporary Mediterranean sepiolid endemism and high species richness, especially in the western area (Mangold and Boletzky, 1988; Bello, 2003; Rosa et al., 2019). Sepiolid systematics and taxonomy rely mostly on the morphology of the light organs or photophores, the male copulatory organ or hectocotylus, and the female sperm storage organ or bursa copulatrix (Reid and Jereb, 2005; Bello, 2020). Three subfamilies are recognized: Heteroteuthinae Appellöf, 1898, Rossiinae Appellöf, 1898 and Sepiolinae Leach, 1817. Even though hectocotylus morphology is a reliable character, recently it was discovered that the previously recognized intraspecific variability in one species undercovered pseudocryptic biodiversity (Groenenberg et al., 2009; de Heij and Goud, 2010). Moreover, identifications based on early life stages and females are challenging and misidentifications are abundant on GenBank (Groenenberg et al., 2009), hindering identification based only on DNA barcoding.

Here, we examined most of the Mediterranean biodiversity for the family Sepiolidae, performed several molecular delimitation methods in order to assess the actual diversity of this group, and provide a solid molecular framework for future studies based on DNA identification methods. Additionally, we discovered a new species of Heteroteuthinae, which is described here using both molecular sequences and morphological characters.

\section{MATERIALS AND METHODS \\ Sample Collection}

In total, 77 newly collected bobtail squids were analyzed (Table 1), covering 12 of the 17 known Mediterranean species and all the genera (Bello, 2015, 2020). Sampled individuals were mostly collected in the Mediterranean coasts of the Iberian Peninsula from Tiñoso Cape in the south to Blanes in the north, including the Balearic Islands, between the years 2006 and 2015. Most of this material was collected during the Spanish research cruises MEDITS 2006 (https://www.sibm.it/ SITO\%20MEDITS/principaleprogramme.htm) and FORMED 5 (Demestre et al., 2017). Additional material were collected by commercial fishing trawlers from Tarragona and Vilanova i la Geltrú fishing ports and from the "sonsera" littoral artisanal fishery from Blanes (Lleonart et al., 2014), which is a small scale littoral boat seine fishing method aimed to catch sand eels. Four individuals of Heteroteuthis dispar (Rüppell, 1844) were collected in NE Atlantic waters near the Canary Islands in the spring of 2015, during the MAFIA research cruise (Olivar et al., 2017). Figure 1 summarized the collection localities. After collection, the individuals were frozen at $-20^{\circ} \mathrm{C}$ until their study in the lab. In a time lapse ranging from a few weeks to 8 years, the material was defrosted, identified, and photographed. From each specimen, a portion of the mantle was removed for DNA extraction and the rest of the body was preserved as a morphological voucher.

\section{Morphological Identification and Vouchering}

Individuals were identified following the morphological key of Bello (1995). In the case of the genera Sepietta (Naef, 1912a) and Sepiola Leach, 1817, only males were identified based on the hectocotylus morphology to ensure reliable identifications. After removal the tissue for DNA extraction, the specimens were fixed in $4 \%$ buffered formalin for 3-10 days and transferred to ethanol $70 \%$. The specimens are deposited in the Biological Reference Collections (CBR-ICM) at the Institut de Ciències del Mar (ICMCSIC, Barcelona, Spain) under the accession numbers provided in Table 1 (Guerrero et al., 2020).

The description provided here for a new butterfly squid is based in a careful morphological examination of all the available specimens $(n=4)$. The measurements and morphometric characters of these specimens followed Roper and Voss (1983) as: dorsal mantle length (DML), ventral mantle length (VML), fin width (FW), fin length (FL), fin base (FB), head width (HW), head length (HL), funnel length (FnL), arm I-IV length (AILAIVL), tentacle length (TeL), tentacle club length (CL), and web depth A-E (WDA-E). Two additional measurements were taken: the occipital band length (mantle-head fusion) (OBL), defined as the length of the fusion between the head and the mantle, and the ventral shield length (VSL), as the shield length along its midline. All the morphological measurements from this study were performed on formaline-fixed individuals stored in $70 \%$ ethanol.

Beaks and radulae were extracted from selected individuals. For the beaks, the upper and lower rostral lengths (URL and LRL, respectively) were measured according to Clarke (1986). The radula was observed under a Hitachi S3500N scanning electron microscope (SEM). At the beginning of SEM preparation, the radulae were dehydrated in an increasing concentration of ethanol (80, 90, and 96\%) until they were saturated in absolute ethanol. Each ethanol bath lasted $10 \mathrm{~min}$. After complete dehydration in the ethanol series, the samples were dried to a critical point using $\mathrm{CO}_{2}$ as the transition liquid. After the drying stage, samples were mounted on stubs with double-sided conductive sticky tape to place them in the preferred position. The mounted samples were sputter coated with gold-palladium before SEM observations.

The spermatophores from selected males were extracted for the assessment of the spermatophore count (SpC), and the spermatophore length $(\mathrm{SpL})$ based on 30 randomly selected spermatophores that were measured according with 
TABLE 1 | List of specimens used in this work, indicating the sampling locality, the number of studied sequences (n), and the GenBank Accession Numbers.

\begin{tabular}{|c|c|c|c|c|c|}
\hline Species & Locality & $n$ & $\begin{array}{l}\text { Morphological } \\
\text { voucher }\end{array}$ & $\begin{array}{c}\text { GenBank Accesion } \\
\text { Number }\end{array}$ & References \\
\hline \multicolumn{6}{|c|}{ Subfamily Rossinae (Appellöf, 1898) } \\
\hline \multirow[t]{2}{*}{ Neorossia caroli (Joubin, 1902) } & $\begin{array}{l}\text { Off Vilanova i la Geltrú, NW } \\
\text { Mediterranean }\end{array}$ & 1 & ICMC000330 & MW261922 & This work \\
\hline & $\begin{array}{l}\text { Alboran Sea, SW Mediterranean } \\
\text { Sea }\end{array}$ & 3 & $\begin{array}{l}\text { ICMC000335- } \\
\text { ICMC000337 }\end{array}$ & MW261922-MW261925 & This work \\
\hline \multirow[t]{4}{*}{$\begin{array}{l}\text { Rossia macrosoma (delle Chiaje, } \\
\text { 1830) }\end{array}$} & $\begin{array}{l}\text { Off Tarragona, NW } \\
\text { Mediterranean Sea }\end{array}$ & 1 & ICMC000329 & MW261927 & This work \\
\hline & $\begin{array}{l}\text { Off Barcelona, NW } \\
\text { Mediterranean Sea }\end{array}$ & 3 & $\begin{array}{l}\text { ICMC000332- } \\
\text { ICMC000334 }\end{array}$ & MW261928-MW261930 & This work \\
\hline & $\begin{array}{l}\text { Off Cartagena, NW } \\
\text { Mediterranean Sea }\end{array}$ & 1 & ICMC000331 & MW261926 & This work \\
\hline & North Sea & 8 & & KM517929-KM517936 & $\begin{array}{l}\text { Gebhardt and } \\
\text { Knebelsberger, } \\
2015\end{array}$ \\
\hline Semirossia tenera (Verrill, 1880) & $\begin{array}{l}\text { Gulf of St. Lawrence, Pacific } \\
\text { Ocean }\end{array}$ & 1 & & AY426436 & $\begin{array}{l}\text { Nishiguchi et al., } \\
2004\end{array}$ \\
\hline \multicolumn{6}{|c|}{ Subfamily Heteroteuthinae (Appellöf, 1898) } \\
\hline \multirow[t]{3}{*}{$\begin{array}{l}\text { Heteroteuthis dagamensis } \\
\text { (Robson, 1924) }\end{array}$} & $\begin{array}{l}\text { Northern Gulf of Mexico, Atlantic } \\
\text { Ocean }\end{array}$ & 1 & & KR606071 & $\begin{array}{l}\text { Judkins et al., } \\
2016\end{array}$ \\
\hline & North Atlantic & 2 & & MT223185, MT219813 & Taite et al., 2020 \\
\hline & New Zealand, SW Pacific & 8 & & MK185916-MK185923 & $\begin{array}{l}\text { Braid and Bolstad, } \\
2019\end{array}$ \\
\hline \multirow{4}{*}{$\begin{array}{l}\text { Heteroteuthis dispar (Rüppell, } \\
\text { 1844) }\end{array}$} & SW Mediterranean Sea & 1 & ICMC000394 & MW261936 & This work \\
\hline & $\begin{array}{l}\text { Off Torrevieja, NW Mediterranean } \\
\text { Sea }\end{array}$ & 2 & $\begin{array}{l}\text { ICMC000393, } \\
\text { ICMC000395 }\end{array}$ & MW261935, MW261937 & This work \\
\hline & $\begin{array}{l}\text { Ebro Delta, NW Mediterranean } \\
\text { Sea }\end{array}$ & 2 & $\begin{array}{l}\text { ICMC000396- } \\
\text { ICMC000397 }\end{array}$ & MW261938-MW261939 & This work \\
\hline & $\begin{array}{l}\text { NE Atlantic Ocean, MAFIA } \\
\text { stations } 11 \text { and } 12 \text { (Olivar et al., } \\
\text { 2017) }\end{array}$ & 3 & & $\begin{array}{c}\text { MW261940 } \\
\text { MW260133-MW260134 }\end{array}$ & This work \\
\hline \multirow[t]{2}{*}{$\begin{array}{l}\text { Heteroteuthis hawaiiensis (Berry, } \\
\text { 1909) }\end{array}$} & & 1 & & AF000044 & $\begin{array}{l}\text { Carlini and Graves, } \\
\text { 1999; Lindgren } \\
\text { et al., } 2004\end{array}$ \\
\hline & & 1 & & AY293728 & $\begin{array}{l}\text { Nishiguchi et al., } \\
2004\end{array}$ \\
\hline $\begin{array}{l}\text { Heteroteuthis ryukyuensis } \\
\text { (Kubodera et al., 2009) }\end{array}$ & $\begin{array}{l}\text { Yonaguni Island, NW Pacific } \\
\text { Ocean }\end{array}$ & 1 & & AB591074 & $\begin{array}{l}\text { Kubodera and } \\
\text { Okutani, } 2011\end{array}$ \\
\hline Heteroteuthis sp. KER & & 1 & & MK185924 & $\begin{array}{l}\text { Braid and Bolstad, } \\
2019\end{array}$ \\
\hline \multirow[t]{2}{*}{$\begin{array}{l}\text { Sepiolina nipponensis (Berry, } \\
\text { 1911) }\end{array}$} & Tosa Bay, NW Pacific Ocean & 1 & & AY293727 & $\begin{array}{l}\text { Nishiguchi et al., } \\
2004\end{array}$ \\
\hline & Tosa Bay, NW Pacific Ocean & 1 & & AB591073 & $\begin{array}{l}\text { Kubodera and } \\
\text { Okutani, } 2011\end{array}$ \\
\hline $\begin{array}{l}\text { Sepiolina petasus Kubodera and } \\
\text { Okutani, } 2011\end{array}$ & $\begin{array}{l}\text { Okinawa Island, NW Pacific } \\
\text { Ocean }\end{array}$ & 1 & & AB591071 & $\begin{array}{l}\text { Kubodera and } \\
\text { Okutani, } 2011\end{array}$ \\
\hline \multirow[t]{3}{*}{ Stoloteuthis cthulhui sp. nov. } & $\begin{array}{l}\text { Balearic Sea, NW Mediterranean } \\
\text { Sea }\end{array}$ & 2 & $\begin{array}{l}\text { ICMC000164- } \\
\text { ICMC000165 }\end{array}$ & MW261931-MW261932 & This work \\
\hline & $\begin{array}{l}\text { Alboran Sea, SW Mediterranean } \\
\text { Sea }\end{array}$ & 1 & ICMC000163 & MW261934 & This work \\
\hline & $\begin{array}{l}\text { Balearic Sea, NW Mediterranean } \\
\text { Sea }\end{array}$ & 1 & ICMC000166 & MW261933 & This work \\
\hline $\begin{array}{l}\text { Stoloteuthis japonica Kubodera } \\
\text { and Okutani, } 2011\end{array}$ & $\begin{array}{l}\text { Okinawa Island, NW Pacific } \\
\text { Ocean }\end{array}$ & 1 & & AB591072 & $\begin{array}{l}\text { Kubodera and } \\
\text { Okutani, } 2011\end{array}$ \\
\hline
\end{tabular}


TABLE 1 | Continued

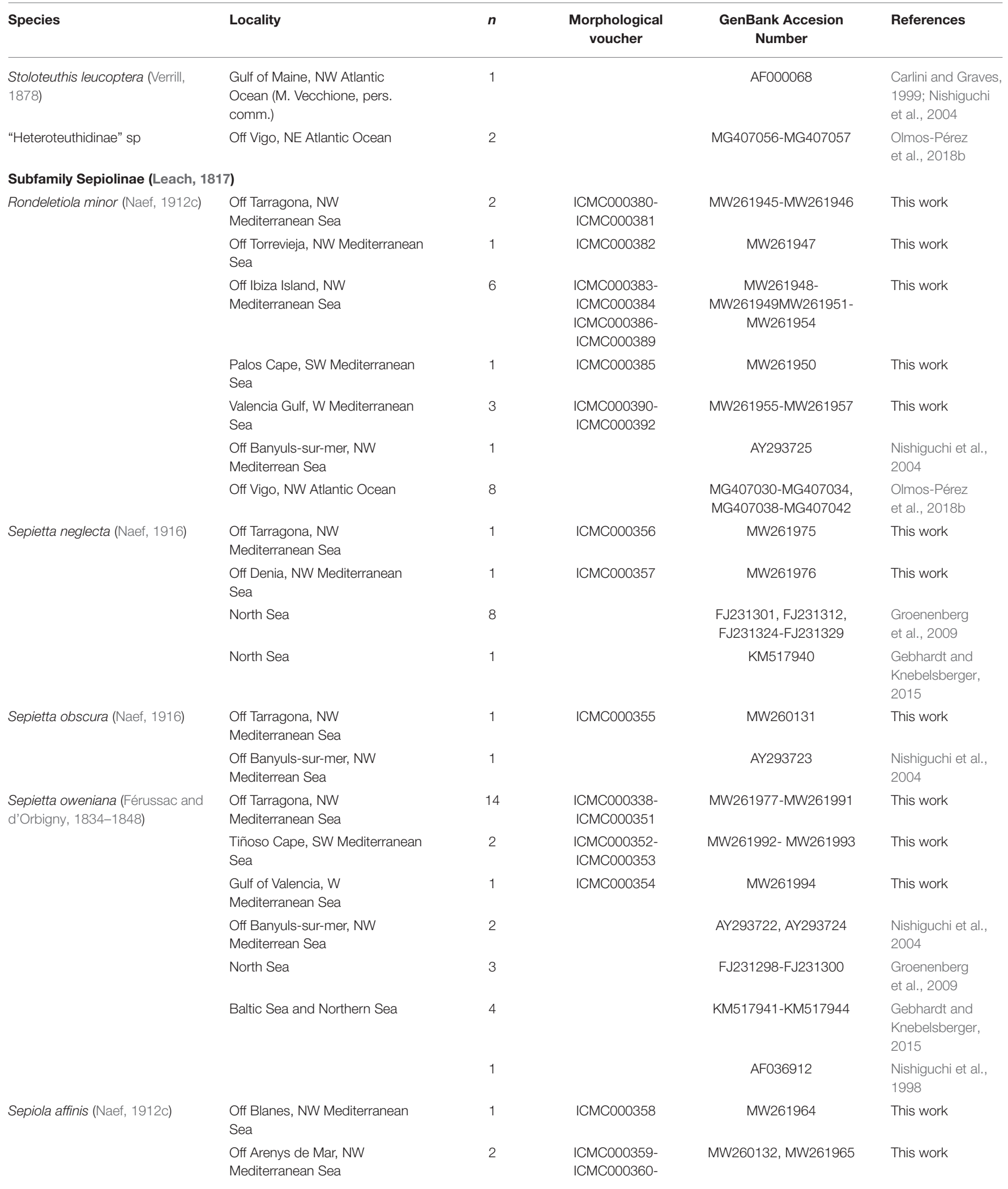


TABLE 1 | Continued

\begin{tabular}{|c|c|c|c|c|c|}
\hline Species & Locality & $n$ & $\begin{array}{l}\text { Morphological } \\
\text { voucher }\end{array}$ & $\begin{array}{c}\text { GenBank Accesion } \\
\text { Number }\end{array}$ & References \\
\hline cf. Sepiola affinis & Adelaide, Pacific Ocean (?) & 1 & & DQ646730 & Jones et al., 2006 \\
\hline & North Sea & 11 & & $\begin{array}{l}\text { FJ231303, FJ231304, } \\
\text { FJ231308-FJ231311, } \\
\text { FJ231314, } \\
\text { FJ231316-FJ231318, } \\
\text { FJ231322 }\end{array}$ & $\begin{array}{l}\text { Groenenberg } \\
\text { et al., } 2009\end{array}$ \\
\hline & Off Vigo, NE Atlantic Ocean & 1 & & AY293721 & $\begin{array}{l}\text { Nishiguchi et al., } \\
2004\end{array}$ \\
\hline & Off Vigo, NE Atlantic Ocean & 1 & & MG407043 & $\begin{array}{l}\text { Olmos-Pérez } \\
\text { et al., 2018b }\end{array}$ \\
\hline & $\begin{array}{l}\text { Off Banyuls-sur-mer, NW } \\
\text { Mediterrean Sea }\end{array}$ & 1 & & AY293720 & $\begin{array}{l}\text { Nishiguchi et al., } \\
2004\end{array}$ \\
\hline \multirow[t]{5}{*}{ Adinaefiola ligulata (Naef, 1912c) } & $\begin{array}{l}\text { Off Tarragona, NW } \\
\text { Mediterranean Sea }\end{array}$ & 1 & ICMC000370 & MW261941 & This work \\
\hline & $\begin{array}{l}\text { Off Torrevieja, NW Mediterranean } \\
\text { Sea }\end{array}$ & 1 & ICMC000371 & MW261942 & This work \\
\hline & $\begin{array}{l}\text { Gulf of Valencia, NW } \\
\text { Mediterranean Sea }\end{array}$ & 2 & $\begin{array}{l}\text { ICMC000372- } \\
\text { ICMC000373 }\end{array}$ & MW261943-MW261944 & This work \\
\hline & $\begin{array}{l}\text { Off Banyuls-sur-mer, NW } \\
\text { Mediterrean Sea }\end{array}$ & 1 & & AY293717 & $\begin{array}{l}\text { Nishiguchi et al., } \\
2004\end{array}$ \\
\hline & Off Vigo, NE Atlantic Ocean & 1 & & MG407045 & $\begin{array}{l}\text { Olmos-Pérez } \\
\text { et al., 2018b }\end{array}$ \\
\hline \multirow[t]{6}{*}{ Sepiola robusta (Naef, 1912c) } & $\begin{array}{l}\text { Off Tarragona, NW } \\
\text { Mediterranean Sea }\end{array}$ & 5 & $\begin{array}{l}\text { ICMC000374- } \\
\text { ICMC000378 }\end{array}$ & MW261959-MW261963 & This work \\
\hline & $\begin{array}{l}\text { Off Alicante, NW Mediterranean } \\
\text { Sea }\end{array}$ & 1 & ICMC000379 & MW261958 & This work \\
\hline & $\begin{array}{l}\text { Off Banyuls-sur-mer, NW } \\
\text { Mediterrean Sea }\end{array}$ & 1 & & AF035710 & $\begin{array}{l}\text { Nishiguchi et al., } \\
1998\end{array}$ \\
\hline & $\begin{array}{l}\text { Off Banyuls-sur-mer, NW } \\
\text { Mediterrean Sea }\end{array}$ & 3 & & $\begin{array}{c}\text { AY293716, AY293718, } \\
\text { AY293719 }\end{array}$ & $\begin{array}{l}\text { Nishiguchi et al., } \\
2004\end{array}$ \\
\hline & Off Vigo, NE Atlantic Ocean & 1 & & AF035707 & $\begin{array}{l}\text { Nishiguchi et al., } \\
1998\end{array}$ \\
\hline & Atlantic Ocean & 1 & & AF035713 & $\begin{array}{l}\text { Nishiguchi et al., } \\
1998\end{array}$ \\
\hline \multirow[t]{2}{*}{$\begin{array}{l}\text { Sepiola tridens (de Heij and } \\
\text { Goud, 2010) }\end{array}$} & North Sea & 16 & & KM517948-KM517963 & $\begin{array}{l}\text { Gebhardt and } \\
\text { Knebelsberger, } \\
2015\end{array}$ \\
\hline & North Sea & 9 & & $\begin{array}{c}\text { FJ231305-FJ231307, } \\
\text { FJ231313, FJ231315, } \\
\text { FJ231319-FJ231321, } \\
\text { FJ231323 }\end{array}$ & $\begin{array}{l}\text { Groenenberg } \\
\text { et al., } 2009\end{array}$ \\
\hline
\end{tabular}


TABLE 1 | Continued

\begin{tabular}{|c|c|c|c|c|c|}
\hline Species & Locality & $n$ & $\begin{array}{l}\text { Morphological } \\
\text { voucher }\end{array}$ & $\begin{array}{c}\text { GenBank Accesion } \\
\text { Number }\end{array}$ & References \\
\hline & Off Vigo, NE Atlantic Ocean & 2 & & MG407054-MG407055 & $\begin{array}{l}\text { Olmos-Pérez } \\
\text { et al., 2018b }\end{array}$ \\
\hline Sepiolinae sp. 1 & & 1 & & AY545194 & $\begin{array}{l}\text { Strugnell et al., } \\
2004\end{array}$ \\
\hline Sepiolinae sp. 2 & & 1 & & AY557523 & $\begin{array}{l}\text { Lindgren et al., } \\
2004\end{array}$ \\
\hline $\begin{array}{l}\text { Lusepiola birostrata (Sasaki, } \\
\text { 1918) }\end{array}$ & Tosa Bay, NW Pacific Ocean & 2 & & AY293710, AY293715 & $\begin{array}{l}\text { Nishiguchi et al., } \\
2004\end{array}$ \\
\hline Euprymna berryi (Sasaki, 1929) & Tosa Bay, NW Pacific Ocean & 1 & & AY293711 & $\begin{array}{l}\text { Nishiguchi et al., } \\
2004\end{array}$ \\
\hline \multirow{2}{*}{$\begin{array}{l}\text { Euprymna hyllebergi } \\
\text { (Nateewathana, 1997) (OTU 1) }\end{array}$} & Rayong, W Pacific Ocean & 3 & & DQ646710-DQ646712 & Jones et al., 2006 \\
\hline & Gulf of Thailand, W Pacific Ocean & 1 & & AY293714 & $\begin{array}{l}\text { Nishiguchi et al., } \\
2004\end{array}$ \\
\hline $\begin{array}{l}\text { Euprymna hyllebergi } \\
\text { (Nateewathana, 1997) (OTU 2) }\end{array}$ & Off Phuket, NE Indian Ocean & 7 & & DQ646703-DQ646709 & Jones et al., 2006 \\
\hline \multirow[t]{2}{*}{$\begin{array}{l}\text { Euprymna scolopes (Berry, } \\
\text { 1913) (OTU1) }\end{array}$} & $\begin{array}{l}\text { Off Hawaii Island, central Pacific } \\
\text { Ocean }\end{array}$ & 10 & & DQ646731-DQ646740 & Jones et al., 2006 \\
\hline & $\begin{array}{l}\text { Kaneohe Bay, Hawaii Island, } \\
\text { central Pacific Ocean }\end{array}$ & 1 & & AF035714 & $\begin{array}{l}\text { Nishiguchi et al., } \\
1998\end{array}$ \\
\hline $\begin{array}{l}\text { Euprymna scolopes (Berry, } \\
\text { 1913) (OTU2) }\end{array}$ & $\begin{array}{l}\text { Off Paiko, Honolulu Island, } \\
\text { central Pacific Ocean }\end{array}$ & 1 & & AY293712 & $\begin{array}{l}\text { Nishiguchi et al., } \\
2004\end{array}$ \\
\hline $\begin{array}{l}\text { Euprymna tasmanica (Pfeffer, } \\
\text { 1884) (OTU 1) }\end{array}$ & Off NW Australia, E Indian Ocean & 1 & & DQ646729 & Jones et al., 2006 \\
\hline $\begin{array}{l}\text { Euprymna tasmanica (Pfeffer, } \\
\text { 1884) (OTU 2) }\end{array}$ & $\begin{array}{l}\text { Off SE Australia, SW Pacific } \\
\text { Ocean }\end{array}$ & 6 & & DQ646722-DQ646727 & Jones et al., 2006 \\
\hline $\begin{array}{l}\text { Euprymna tasmanica (Pfeffer, } \\
\text { 1884) (OTU 3) }\end{array}$ & Off NW Australia, E Indian Ocean & 1 & & DQ646728 & Jones et al., 2006 \\
\hline \multirow[t]{2}{*}{$\begin{array}{l}\text { Euprymna tasmanica (Pfeffer, } \\
\text { 1884) (OTU 4) }\end{array}$} & $\begin{array}{l}\text { Off SW Australia, SW Pacific and } \\
\text { SE Indian Oceans }\end{array}$ & 9 & & DQ646713-DQ646721 & Jones et al., 2006 \\
\hline & $\begin{array}{l}\text { Off Melbourne, SW Pacific } \\
\text { Ocean }\end{array}$ & 1 & & AY293713 & $\begin{array}{l}\text { Nishiguchi et al., } \\
2004\end{array}$ \\
\hline \multicolumn{6}{|l|}{ Outgroup } \\
\hline \multicolumn{6}{|l|}{$\begin{array}{l}\text { Sepiadariidae Fischer, } 1882 \text { in } \\
\text { 1880-1887 (Fischer, } \\
1880-1887 \text { ) }\end{array}$} \\
\hline $\begin{array}{l}\text { Idiosepius pygmaeus } \\
\text { (Steenstrup, 1881) }\end{array}$ & & 1 & & AF000046 & $\begin{array}{l}\text { Carlini and Graves, } \\
\text { 1999; Lindgren } \\
\text { et al., } 2004\end{array}$ \\
\hline
\end{tabular}

Nigmatullin et al. (2003). The specimen ICMC000165 had intact spermatophores, while in the remaining studied animals the spermatophoric reaction was triggered (Marian, 2015). Sixteen spermatophores from these males were used to make the following spermatophore measurements: head $(\mathrm{SpH})$, ejaculatory tube $(\mathrm{SpE})$, cement body (SpCe), seminal reservoir $(\mathrm{SpS})$, and posterior empty part (SpEm). As comparative morphological material, eight males and seven females of Stoloteuthis leucoptera (Verrill, 1878), collected off Namibia (Villanueva and Sánchez, 1993) and deposited at the CBR-ICM under the accession numbers ICMC000167-ICMC000181, were examined.

Following the recommendation number 11 from the Appendix B of the International Code of Zoological Nomenclature (International Commission on Zoological Nomenclature, 1999), we set up four abbreviations to unambiguously refer to the four genera starting with " $S$ " mentioned in this work: "S." for Sepiola, "St." for Sepietta, "Sl." for Stoloteuthis and "Se." for Sepiolina (Naef, 1912b).

\section{DNA Extraction, Amplification, and Sequencing}

Tissues for molecular analysis were fixed in $96 \%$ ethanol. Total genomic DNA was extracted from an ethanol-fixed piece of the mantle using the NZY Tissue gDNA isolation kit (NZYTech, Lisbon, Portugal), following the manufacturers' protocol and resuspended in a final volume of $100 \mu \mathrm{L}$. A negative control that contained no sample was included in every isolation round to check for contamination during the experiments. Sequences from the partial mitochondrial cytochrome $c$ oxidase I (COI) gene were amplified, using the primer pair LCO1490 and HCO2198 


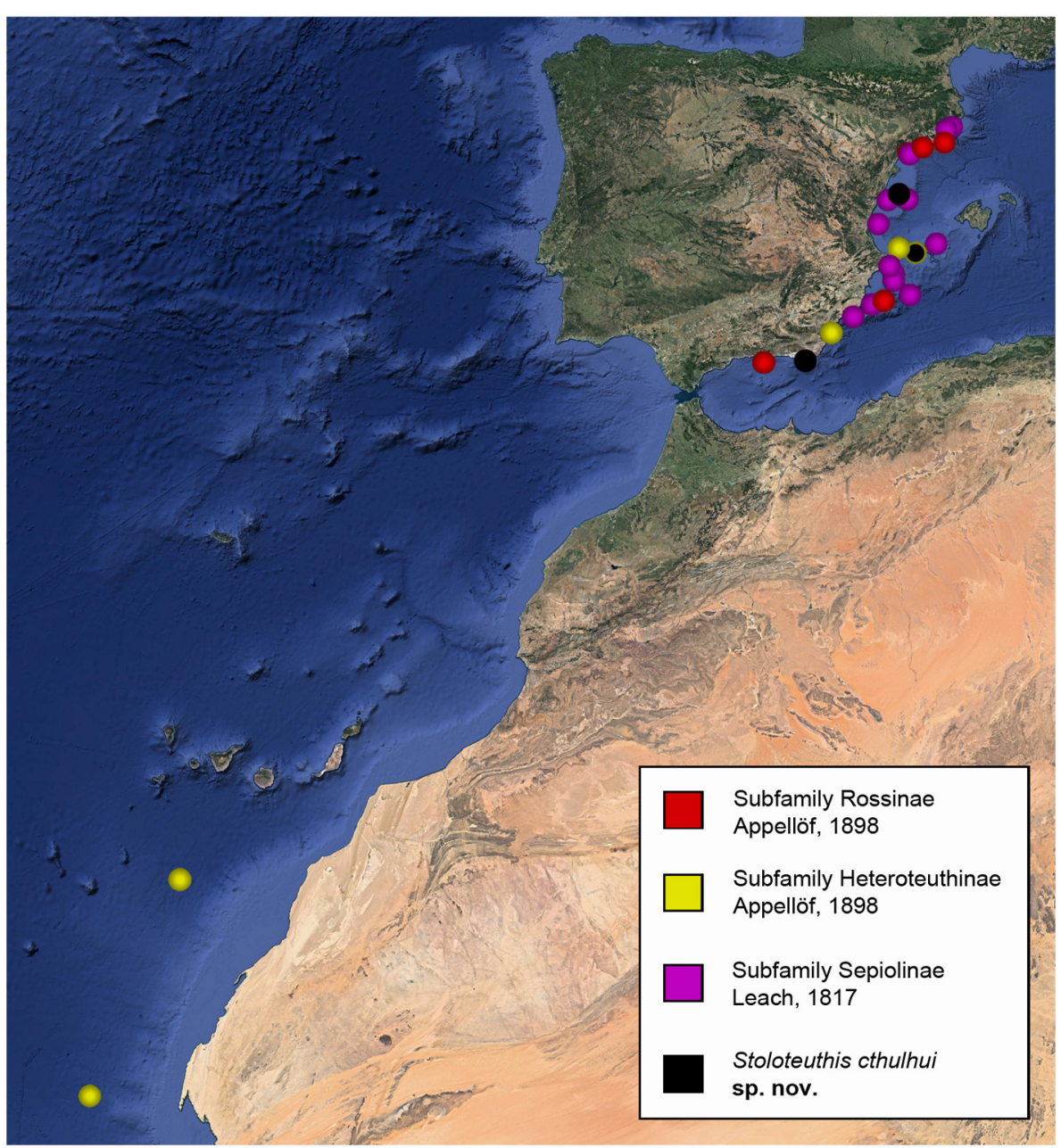

FIGURE 1 | Sampling localities of the specimens sequenced in this work sorted by subfamilies. Sampling localities of Stoloteuthis cthulhui sp. nov. are also indicated. Modified from Google Earth Pro.

(Folmer et al., 1994). Standard PCR reactions were performed using the NZYTaq Green PCR Master Mix (NZYTech, Portugal) following the manufacturer's protocol in a total volume of $25 \mathrm{~mL}$, which included $0.5 \mu \mathrm{M}$ of each primer, $25 \mathrm{ng}$ of template DNA and PCR-grade water up to $25 \mu \mathrm{L}$. PCRs consisted of an initial denaturation at $95^{\circ} \mathrm{C}$ for $5 \mathrm{~min}$, followed by 35 cycles of denaturation at $95^{\circ} \mathrm{C}$ for $30 \mathrm{~s}$, annealing at $50^{\circ} \mathrm{C}$ for $30 \mathrm{~s}$ and extension at $72^{\circ} \mathrm{C}$ for $45 \mathrm{~s}$, with a final extension of $5 \mathrm{~min}$ at $72^{\circ} \mathrm{C}$. The amplified products were sequenced using both forward and reverse PCR primers on an ABI 3730xl. DNA sequence data were edited and aligned with Geneious 8.1.5 (http://www.geneious. com). The GenBank Accession numbers of the sequences used in this work together with the morphological voucher Accession numbers are summarized in Table $\mathbf{1}$.

\section{Phylogenetic Analyses}

The new sequences obtained in this work together with selected sequences available from GenBank were analyzed (Table 1). Idiosepius pygmaeus (Steenstrup, 1881) was selected as outgroup for the phylogenetic analyses. Some sequences coming from GenBank were shorter, so Ns were added to align them with the complete sequences. The final alignment contained 245 sequences and 658 positions. As an initial analysis, a Maximum Likelihood tree was obtained through the IQTree portal (Trifinopoulos et al., 2016) [available at http://iqtree.cibiv. univie.ac.at] using the automatic model selection feature. The selected model was TIM2+F+I+G4 according to both Akaike and Bayesian Informative Criteria. The support of the branches was calculated after 2,000 ultrafast bootstrap generations.

Several molecular species delimitation analyses were performed. The online version of software Automatic Barcode Gap Discovery (ABGD, Puillandre et al., 2012) [available at https://bioinfo.mnhn.fr/abi/public/abgd/abgdweb.html] was used to check the distribution and size of a potential barcoding gap. Previous empirical studies have shown that individuals assigned to a statistical parsimony network with a 95\% probability for COI usually correspond to species (Pons et al., 2006; Hart and Sunday, 2007; Bond and Stockman, 2008; 
TABLE 2 | Interspecific mean p-distance percenteages (\%) between sepiolid taxa.

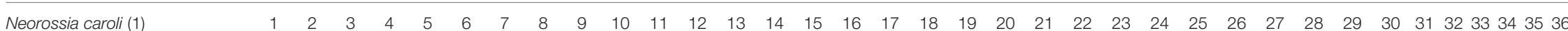

11.1

Semirossia tenera (3) $\quad 4.1112$

Heteroteuthis dagamensis (4) $\quad 12.913 .615 .2$

Heteroteuthis dispar (5) $\quad 14.215 .116 .44 .28$

Heteroteuthis hawaiinensis (6) $\quad 13.414 .215 .74 .363 .27$

Heteroteuthis ryukuensis (7) $\quad 14.914 .215 .811 .512 .811 .7$

Heteroteuthis sp. KER (8) $\quad 12.713 .715 .23 .852 .872 .5411 .8$

Sepiolina nipponensis (9) $\quad 14.415 .315 .411 .81413 .69 .5313 .8$

Sepiolina petasus (10) $\quad 14.9 \quad 16 \quad 15.6 \quad 12 \quad 13.213 .310 .8 \quad 12 \quad 14$

Stoloteuthis cthulhui sp. nov. (11) 13.514 .314 .512 .713 .512 .913 .112 .612 .514 .7

Stoloteuthis leucoptera (12) $\quad 13.413 .514 .812 .814 .212 .711 .213 .211 .614 .43 .5$

Stoloteuthis japonica (13) $\quad$ 13.614.914.6 $12 \quad 13.412 .79 .1312 .82 .4312 .812 .911 .6$

"Heteroteuthidinae" sp. (14) $\quad \begin{array}{llllllll}13.3 & 13 & 13.9 & 13 & 12.911 .7 & 12.711 .913 .7 & 13.913 .412 .513 .1\end{array}$

Rondeletiola minor (15) $\quad 1415.315 .315 .816 .615 .913 .715 .813 .814 .71615 .113 .114 .8$

Sepietta neglecta (16) $\quad 14.7 \quad 1414.813 .415 .114 .61214 .211 .612 .613 .612 .611 .612 .111 .3$

Sepietta obscura (17)

Sepietta oweniana (18)

Sepiola affinis (19)

Sepiola atlantica (20)

Sepiola intermedia (21)

Adinaefiola ligulata (22)

Adinaefiola pfefferi (23)

Sepiola robusta (24)

Sepiola tridens (25)

Sepiolinae sp. 1 (26)

Sepiolinae sp. 2 (27)

Lusepiola birrostrara (28)

Euprymna berryi (29)

$14.415 .115 .511 .312 .111 .89 .4311 .99 .6310 .813 .812 .19 .6312 .212 \quad 8.64$

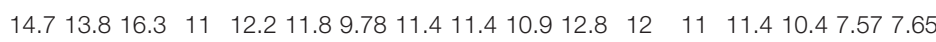

$14.21414 .811 .112 .211 .79 .8911 .710 .210 .513 .111 .39 .4811 .411 .69 .96 \quad 7.3 \quad 8.46$

$14.313 .814 .611 .212 .211 .89 .9411 .89 .9410 .313 .511 .49 .5311 .311 .710 .67 .2 \quad 8.360 .81$

$13.813 .414 .110 .811 .811 .49 .5511 .49 .519 .9213 .111 \quad 9.5110 .912 \quad 10.16 .827 .931 .451 .08$

$13.215 .313 .812 .613 .813 .211 .813 .2 \quad 11 \quad 12 \quad 13.112 .410 .312 .713 .810 .810 .211 .810 .110 .310 .3$

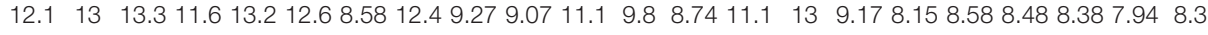

14.514 .415 .112 .513 .713 .912 .813 .112 .511 .415 .114 .912 .412 .713 .811 .911 .610 .210 .510 .49 .9610 .89 .26

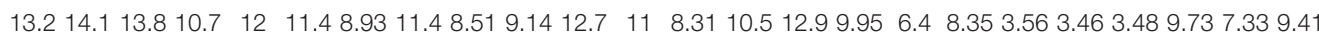

$1515.616 .413 .414 .614 .113 .613 .813 .813 \quad 13.913 .814 \quad 14.515 .913 .612 .112 .414 \quad 1413.512 .812 .914 .713 .2$

$13 \quad 13.914 .411 .112 .412 .111 .8 \quad 12 \quad 11.412 .213 .112 .8 \quad 11 \quad 13.113 .712 .49 .849 .469 .489 .539 .5511 .69 .6611 .58 .5313 .4$

$12.813 .413 .713 .413 .913 .713 .512 .813 .911 .114 \quad 13.913 .713 .214 .111 .711 .310 .910 .810 .710 .211 .110 .212 .810 .314 .112 .3$

$14.915 .215 .813 .813 .813 .112 .613 .2 \quad 15 \quad 13 \quad 14.4 \quad 14 \quad 14.413 .916 .114 .414 .113 .813 .313 .412 .911 .8 \quad 12 \quad 14.913 .4 \quad 12 \quad 14 \quad 12.3$

Euprymna hyllebergi (OTU 1) (30) 16.416 .917 .815 .815 .616 .312 .715 .414 .414 .616 .615 .412 .914 .716 .314 .814 .112 .813 .91413 .712 .711 .514 .813 .312 .314 .415 .511 .3

Euprymna hyllebergi (OTU 2) (31) 14.616 .816 .413 .915 .31511 .614 .113 .314 .315 .91512 .214 .216 .114 .512 .812 .113 .613 .613 .612 .910 .714 .112 .611 .913 .514 .510 .93 .99

Euprymna scolopes (OTU 1) (32) 1514.916 .414 .415 .414 .513 .813 .51615 .315 .115 .115 .314 .214 .814 .414 .61213 .513 .513 .515 .913 .61513 .513 .712 .913 .610 .912 .712

Euprymna scolopes (OTU 2) (33) $14.914 .816 .214 .215 .214 .313 .813 .415 .815 .2 \quad 15 \quad 15 \quad 15.214 .115 \quad 14.214 .511 .813 .313 .413 .415 .813 .414 .913 .413 .612 .813 .510 .812 .612 \quad 0.3$

Euprymna tasmanica (OTU 1) (34) $15.516 .216 .612 .713 .413 .312 .212 .613 .813 \quad 14.314 .212 .814 .31613 .412 .11213 .513 .613 .213 .811 .313 .312 .410 .813 .413 .911 .213 .1121112$

Euprymna tasmanica (OTU 2) (35) $16.917 .617 .215 .815 .715 .513 .215 .414 .814 .716 .315 .514 .315 .515 .613 .613 .913 .414 .614 .614 .314 .712 .914 .814 .213 .714 \quad 1512.612 .612141412$

Euprymna tasmanica (OTU 3) (36) $15.517 .515 .814 .615 .615 .512 .414 .814 \quad 14 \quad 1514.614 .215 .115 .812 .813 .513 .113 .213 .41313 .411 .814 .513 .811 .614 .613 .911 .210 .99 .61212108$

Euprymna tasmanica (OTU 4) (37) $15 \quad 16.615 .114 .815 .815 .611 .815 .113 .713 .715 .413 .913 .515 .516 .312 .812 .612 .713 .613 .312 .913 .910 .913 .312 .7 \quad 12 \quad 13.714 .212 .210 .89 .212129 .7 \quad 9 \quad 4.4$

Euprymna hyllebergi, Euprymna scolopes, and Euprymna tasmanica were splitted in several OTUs (see Material and Methods section for more details). 
Kang et al., 2015), so the software TCS v.1.21 (Clement et al., 2000) was used to construct haplotype networks with a maximal connectivity limits of 95, 98, and 99\%. Bayesian Poisson Tree Processes (bPTP; Zhang et al., 2013) was applied through the bPTP portal [http://species.h-its.org/ptp/]. The initial tree was the Maximum Likelihood tree obtained by IQTree, and the bPTP portal was used with the default parameters. For the Generalized Mixed Yule Coalescent approach (GMYC, Fujisawa and Barraclough, 2013), a Bayesian analysis under a lognormal relaxed clock was performed with Beast v1.10.4 (Drummond and Rambaut, 2007) in the CIPRES server (Miller et al., 2010) using the TN93 gamma model for 100 million generations sampled each 10,000 generations. Tracer v1.6 (Rambaut and Drummond, 2003-2009) was used to check whether the parameter had reached values of effective sample size over 100 and a burn-in of 25\% was applied through TreeAnnotator v.1.10.4 (Drummond and Rambaut, 2007). The resulting maximum credibility tree was visualized and converted to Newick format with FigTree v1.4.4 (Rambaut, 2006-2009) and submitted to the GMYC web server [http://species.h-its.org/gmyc/] by both the single and multi-threshold methods.

Uncorrected genetic distances ( $p$-distances) between and within species (excluding the outgroup taxa) were calculated with MEGA6 (Tamura et al., 2013). The specific labels employed here were defined according with the morphological identification of the morphological vouchers or the taxonomic labels provided in the original work (Table 1). Euprymna hyllebergi (Nateewathana, 1997), Euprymna scolopes (Berry, 1913) and Euprymna tasmanica (Pfeffer, 1884) showed intraspecific distances larger than those found at an interspecific level between other species of the dataset and identified as different species by some of the molecular species delimitation methods. Therefore, they were, respectively, split into two to four Operational Taxonomic Units (OTUs) in the genetic divergence analyses (Tables 1-3).

When possible, species identifications of the clades were based on voucher specimens. Several sequences uploaded to GenBank from previous works were originally based on misidentified specimens. The correct identifications, the original identifications, their GenBank Accession numbers and the original references are summarized in Table 4.

\section{RESULTS}

\section{Molecular Species Delimitation}

Thirty seven different clades of bobtail squids were identified based on molecular and morphological data (Figure 2). The individuals examined in the present study and identified based on morphological characters always clustered together in a single clade, but some inconsistencies were detected on previously published sequences. Some of them are amended according with our identifications over other members of their respective clades (Table 4). Sepiolinae sp. 1 was not originally identified at the species level (Strugnell et al., 2004) and the only sequence available did not match with any correctly identified clade. Sepiolinae sp. 2 was originally identified as Sepiola affinis (Naef, 1912c) (Lindgren et al., 2004; Table 4), but this sequence did not group with the correctly identified S. affinis. The sequences
TABLE 3 | Intrapecific $p$-distance percenteages (\%).

\begin{tabular}{|c|c|c|c|}
\hline Species & Mean & Range & $n$ \\
\hline Neorossia caroli & 0.1 & $0-0.2$ & 4 \\
\hline Rossia macrosoma & 0.75 & $0-1.4$ & 13 \\
\hline Semirossia tenera & $\mathrm{N} / \mathrm{A}$ & $\mathrm{N} / \mathrm{A}$ & 1 \\
\hline Heteroteuthis dagamensis & 0.38 & $0-2.2$ & 11 \\
\hline Heteroteuthis dispar & 0.05 & $0-0.2$ & 8 \\
\hline Heteroteuthis hawaiinensis & 1.42 & $\mathrm{~N} / \mathrm{A}$ & 2 \\
\hline Heteroteuthis ryukyuensis & $\mathrm{N} / \mathrm{A}$ & $\mathrm{N} / \mathrm{A}$ & 1 \\
\hline Heteroteuthis sp. KER & $\mathrm{N} / \mathrm{A}$ & $\mathrm{N} / \mathrm{A}$ & 1 \\
\hline Sepiolina nipponensis & 0 & $\mathrm{~N} / \mathrm{A}$ & 2 \\
\hline Sepiolina petasus & $\mathrm{N} / \mathrm{A}$ & $\mathrm{N} / \mathrm{A}$ & 1 \\
\hline Stoloteuthis cthulhui sp. nov. & 0.24 & $0-0.3$ & 4 \\
\hline Stoloteuthis japonica & $\mathrm{N} / \mathrm{A}$ & $\mathrm{N} / \mathrm{A}$ & 1 \\
\hline Stoloteuthis leucoptera & $\mathrm{N} / \mathrm{A}$ & $\mathrm{N} / \mathrm{A}$ & 1 \\
\hline "Heteroteuthidinae" sp. & 0.2 & $\mathrm{~N} / \mathrm{A}$ & 2 \\
\hline Rondeletiola minor & 0.44 & $0-1.2$ & 14 \\
\hline Sepietta neglecta & 0.04 & $0-0.2$ & 11 \\
\hline Sepietta obscura & 0.2 & $\mathrm{~N} / \mathrm{A}$ & 2 \\
\hline Sepietta oweniana & 0.24 & $0-0.6$ & 28 \\
\hline Sepiola affinis & 0.34 & $0-0.8$ & 3 \\
\hline Sepiola atlantica & 0 & 0 & 14 \\
\hline Sepiola intermedia & 0.12 & $0-0.6$ & 10 \\
\hline Adinaefiola ligulata & 0 & $0-0.5$ & 5 \\
\hline Adinaefiola pfefferi & 0.3 & 0 & 5 \\
\hline Sepiola robusta & 0.27 & $0-1.8$ & 12 \\
\hline Sepiola tridens & 0.02 & 0 & 25 \\
\hline Sepiolinae sp 1 & $\mathrm{~N} / \mathrm{A}$ & $\mathrm{N} / \mathrm{A}$ & 1 \\
\hline Sepiolinae sp 2 & N/A & $\mathrm{N} / \mathrm{A}$ & 1 \\
\hline Lusepiola birostrata & 0.2 & $\mathrm{~N} / \mathrm{A}$ & 2 \\
\hline Euprymna berryi & $\mathrm{N} / \mathrm{A}$ & $\mathrm{N} / \mathrm{A}$ & 1 \\
\hline Euprymna hyllebergi (OTU 1) & 0.1 & $0-0.3$ & 4 \\
\hline Euprymna hyllebergi (OTU 2) & 0.41 & $0-0.6$ & 7 \\
\hline Euprymna scolopes (OTU 1) & 0.28 & $0-0.8$ & 11 \\
\hline Euprymna scolopes (OTU 2) & $\mathrm{N} / \mathrm{A}$ & $\mathrm{N} / \mathrm{A}$ & 1 \\
\hline Euprymna tasmanica (OTU 1) & $\mathrm{N} / \mathrm{A}$ & $\mathrm{N} / \mathrm{A}$ & 1 \\
\hline Euprymna tasmanica (OTU 2) & 0.18 & $0.2-0.9$ & 6 \\
\hline Euprymna tasmanica (OTU 3) & $\mathrm{N} / \mathrm{A}$ & $\mathrm{N} / \mathrm{A}$ & 1 \\
\hline Euprymna tasmanica (OTU 4) & 0.35 & $0-0.8$ & 10 \\
\hline
\end{tabular}

Euprymna hyllebergi, Euprymna scolopes, and Euprymna tasmanica were split in severa OTUs (see section Material and Methods for more details). N/A, not available.

AY293710 and AY293715 were described as Lusepiola birostrata (Sasaki, 1918) or Euprymna morsei (Verrill, 1881) and their divergence is compatible with an intraspecific distance. Sanchez et al. (2019) assigned those sequences to Sepiola (= Lusepiola) birostrata. Euprymna hyllebergi, E. scolopes, and E. tasmanica showed 2-4 highly divergent clades.

The species delimitation methods provided conflicting results. The eight partitions of the ABGD identified from 26 to 41 groups depending of the prior maximal distance. It identified 28 groups with a maximal intragroup distance of $2.1 \%, 33$ groups with maximal distances of $0.04-1.2 \%$ and 41 groups 
TABLE 4 | Misidentifications from GenBank.

\begin{tabular}{|c|c|c|c|}
\hline Species & Originally identified as & GenBank Accession number & References \\
\hline Sepietta oweniana & Sepietta neglecta & AY293722 & Nishiguchi et al., 2004 \\
\hline Sepietta oweniana & Euprymna stenodactyla & AF035704* & Nishiguchi et al., 1998 \\
\hline Sepietta oweniana & Sepietta obscura & AF036912 & $\begin{array}{l}\text { It is not included in } \\
\text { Nishiguchi et al. (1998) } \\
\text { although it is indicated } \\
\text { as such in GenBank. }\end{array}$ \\
\hline cf. Sepiola affinis & Euprymna tasmanica & DQ646730 & Jones et al., 2006 \\
\hline Sepiola intermedia & Sepiola affinis & AF035706* & Nishiguchi et al., 1998 \\
\hline Sepiola intermedia & Sepiola rondeleti & AY293720 & Nishiguchi et al., 2004 \\
\hline Sepiola robusta & Sepiola atlantica & AF035707 & Nishiguchi et al., 1998 \\
\hline Sepiola robusta & Adinaefiola ligulata & AF035710 & Nishiguchi et al., 1998 \\
\hline Sepiola robusta & Heteroteuthis dispar & AF035713 & Nishiguchi et al., 1998 \\
\hline Sepiola robusta & Sepiola affinis & AY293716 & Nishiguchi et al., 2004 \\
\hline Sepiola robusta & Sepiola intermedia & AY293718 & Nishiguchi et al., 2004 \\
\hline Sepiolinae sp. 2 & Sepiola affinis & AY557523 & Lindgren et al., 2004 \\
\hline Euprymna scolopes & Rondelentiola minor & AF035714 & Nishiguchi et al., 1998 \\
\hline Euprymna scolopes & Euprymna morsei & AF035702 & Nishiguchi et al., 1998 \\
\hline
\end{tabular}

*The sequence presented stop signals. They were considered pseudogenes and excluded from the phylogenetic analyses.

The correct species, the original identification, the GenBank Accesion, and the original reference numbers are indicated.

for $0.2-0.1$ maximal distances. Based on the distribution of the distances of the whole dataset, no discrete barcoding gap was detected. Figure 2 represents the species assemblages based on the results from $A B G D$ with a maximal distance prior of $1.2 \%$, since it is closer to the observed maximal intra-specific distance observed in the dataset. The TCS analysis with $95 \%$ of maximum connectivity identified 34 networks. Sepiola affinis, Sepiola atlantica d'Orbigny, 1842 in Férussac and d'Orbigny, 1834-1848, and Sepiola intermedia (Naef, 1912d) formed a single network, while E. hyllebergi, E. scolopes, and E. tasmanica were split in 2-4 networks (Figure 2). The TCS analyses at 98 and $99 \%$ of divergence differed in the relations between S. affinis, S. atlantica, S. intermedia and the sequence DQ646730 (identified as E. tasmanica). In the $99 \%$ analysis, the three species and DQ646730 formed four independent networks, while in the 98\% analysis S. affinis, S. atlantica, and DQ646730 formed a single network. Both 98 and 99\% analyses over-split Rossia macrosoma (delle Chiaje, 1830), Heteroteuthis dagamensis (Robson, 1924), Heteroteuthis hawaiinensis (Berry, 1909), and Sepiola robusta (Naef, 1912c) in two networks each. The Maximum Likelihood solution of the bPTP analysis recovered 38 species majorly consistent with the results of the TCS 95\% analysis and the morphological and molecular assignations of the Maximum Likelihood tree (Figure 1). However, two species were detected for E. scolopes OTU 1 and three for $H$. dagamensis (one including all New Zealand specimens and the two others included North Atlantic specimens); and S. affinis, S. atlantica, and $S$. intermedia were recognized as a single species. The highest Bayesian supported solution recognized 83 species, and $S$. intermedia was recognized as a different species than $S$. affinis and $S$. atlantica (results not shown). The single threshold method of the GMYC identified 28 clusters (confidence interval 20-32) and 41 entities (confidence interval 26-48) with a significant Likelihood Ratio test $(\mathrm{LR}=4.312508 \mathrm{e}-07)$. Sepiola affinis including the sequence DQ646730, S. atlantica and $S$. intermedia were recognized as three independent species. Two species were recognized for $H$. dagamensis: one including all the Atlantic individuals and another formed by the New Zealand specimens. Rossia macrosoma and Rondeletiola minor (Naef, 1912c) were split in two species each. The multi-threshold method revealed 31 clusters (confidence interval 24-31) and 43 entities (confidence interval 31-43) also with a significant result $(\mathrm{LR}=1.928034 \mathrm{e}-08)$. In this analysis $S$. affinis including the sequence DQ646730 and S. intermedia were recognized as independent species, but $S$. atlantica was recognized as two species. Rossia macrosoma, E. hyllebergi OTU 2 and Sepietta oweniana d'Orbigny in Férussac and d'Orbigny, 1834-1848 were also recognized as two species each, while E. tasmanica OTUs 3 and 4, and Stoloteuthis japonica Kubodera and Okutani, 2011 and Sepiolina nipponensis (Berry, 1911) were merged in single species. It also split Atlantic and New Zealand H. dagamensis in two different species.

Uncorrected $p$-distances across species ranged from 0.81 to 18\% (Table 2; mean: $12.7 \%$ ) and from 0 to 2.3\% (Table 3; mean: $0.3 \%)$ at an intraspecific level. Regarding interclade distances, it should be noted that most interspecific distances were values above 3\% [in accordance to the values for the family Sepiolidae published by Gebhardt and Knebelsberger (2015)], but the distances were lower between Se. nipponensis and Sl. japonica (2.4\%); H. dispar, Heteroteuthis sp. KER [from the Kermadec Islands, see Braid and Bolstad (2019)] and H. hawaiinensis (2.5$2.8 \%$ ); and between S. intermedia, S. atlantica, and S. affinis $(1.45 \%)$. The identification of the last three species is assured since it was confirmed morphologically (Groenenberg et al., 


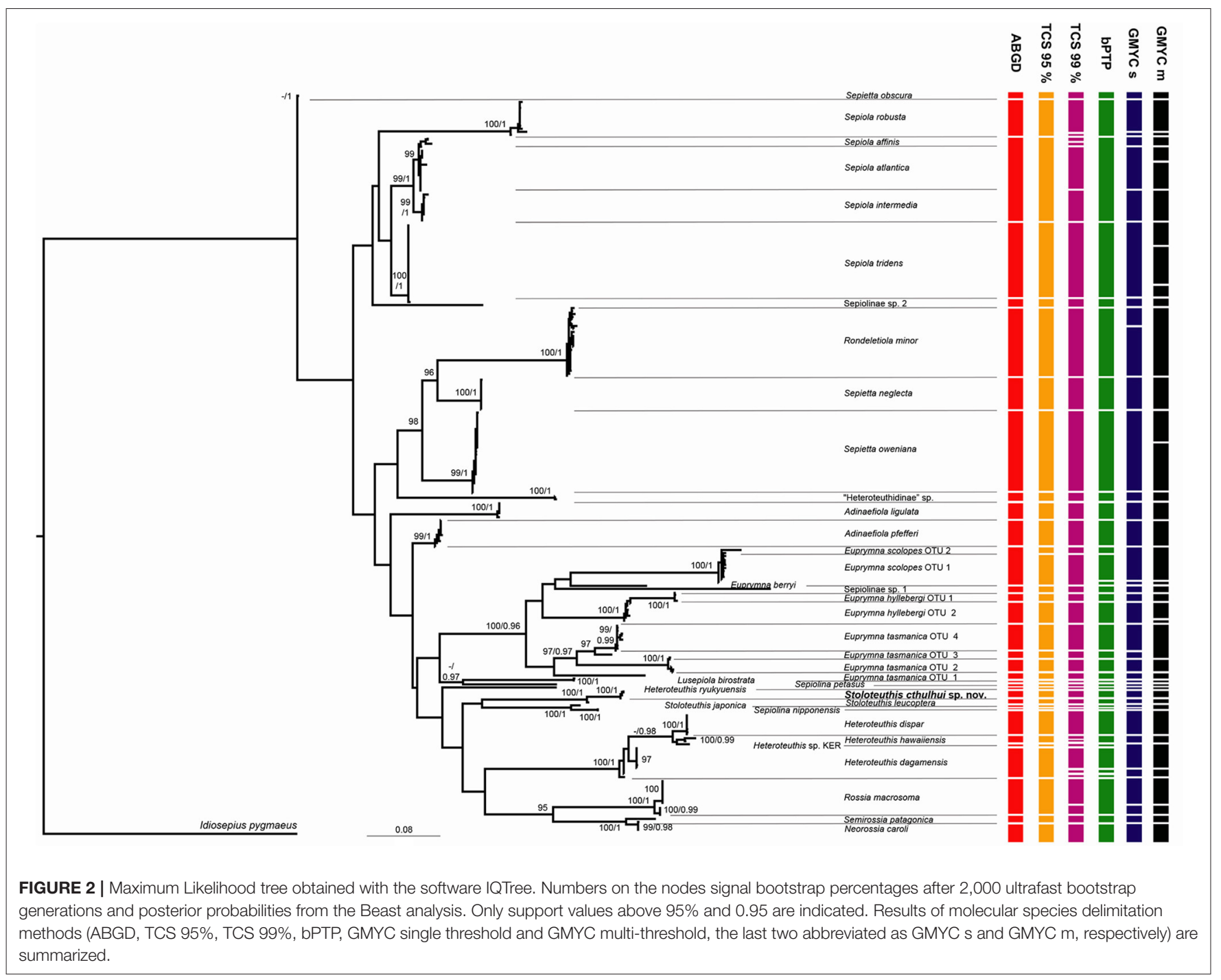

2009 for S. atlantica; this work for S. affinis and S. intermedia, Figure 3). Regarding intraclade distances, in $H$. dagamensis distances above $2 \%$ were reported (Table 2 ).

Among the analyzed Rossinae species [Neorossia caroli (Joubin, 1902), Rossia macrosoma (delle Chiaje, 1830), and Semirossia tenera (Verrill, 1880)] interspecific distances ranged from 4 to $12.2 \%$ (Table 2) and at intraspecific level ranged between 0 and $1.4 \%$. Among $R$. macrosoma two different clades diverging $1.4 \%$ were identified. One of them was formed by four Mediterranean individual while the other one was formed by one Mediterranean and eight North Sea individuals. Among Heteroteuthinae, interspecific $p$-distances ranged from 2.4 to $17.8 \%$ (Table 2) and the intraspecific $p$-distances range was $0-2.2 \%$ (Table 3). Between the Mediterranean Stoloteuthis individuals and Sl. leucoptera the distance levels were typical for interspecific distances. Among Sepiolinae, the interspecific $p$ distances ranged from 0.81 to $15.8 \%$, but if S. affinis, S. atlantica and $S$. intermedia are excluded, the lowest intraspecific distance detected is $3.4 \%$ and there is no overlapping between intra- and interclade $p$-distances (Tables 2, 3), as occurs in the other available sequences of the other two subfamilies. In the genus Euprymna (Steenstrup, 1887), cryptic biodiversity was found in E. hyllebergi and E. tasmanica, formed by 2 and 4 highly divergent clades, respectively (Figure 2, Tables 2, 3). Between the two clades of E. hyllebergi, a distance of $3.9 \%$ was reported. Distances of $4.3-11.6 \%$ are found between the four divergent clades of E. tasmanica. The TCS and bPTP analyses found cryptic biodiversity in E. scolopes, although the ABGD, the GMYC, and the $p$-distance analyses did not find it.

\section{Systematics}

Subfamily Heteroteuthinae Appellöf, 1898

Genus Stoloteuthis Verrill, 1881

Stoloteuthis cthulhui

sp. nov.

(Figure 4, Tables 5, 6)

Stoloteuthis leucoptera- Orsi Relini and Massi (1991)

Stoloteuthis leucoptera- Volpi et al. (1995) 


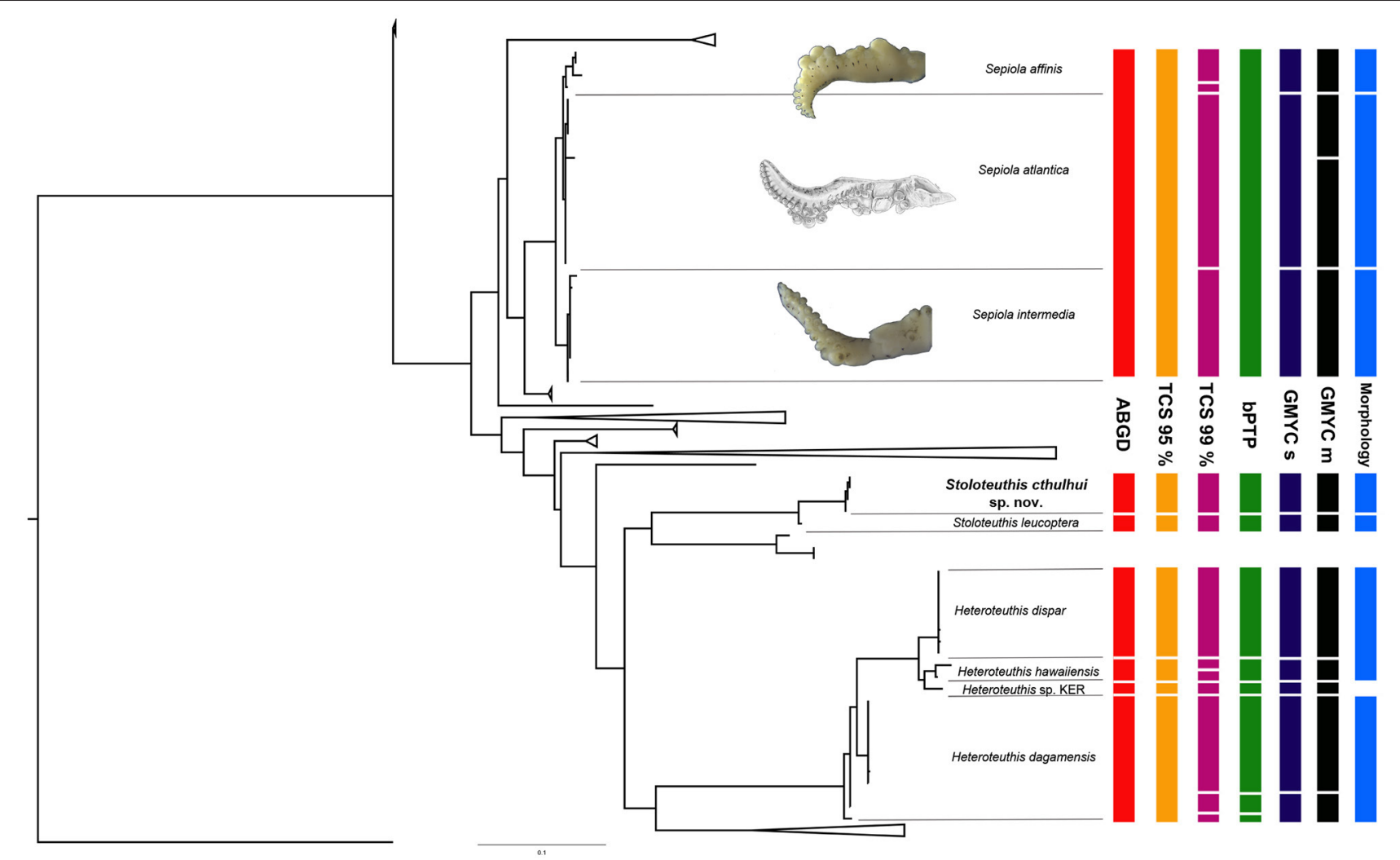

FIGURE 3 | Selected clades of the Maximum Likelihood tree depicted in Figure 2. A summary of the species delimitation based on molecular methods (ABGD, TCS 95\%, TCS 99\%, bPTP, GMYC single threshold, and GMYC multi-threshold, the last two abbreviated as GMYC s and GMYC m, respectively) and morphology is provided at the right of the phylogenetic tree. Morphological diferences for the depicted species of the genus Sepiola is based in our material and de Heij and Goud (2010); for Stoloteuthis cthulhui sp. nov. and Stoloteuthis leucoptera based on the results of this study; and for Heteroteuthis spp. based on Vecchione and Young (2007), Judkins et al. (2016), and Braid and Bolstad (2019). Sepiola atlantica hectocotylus reproduced with permission from de Heij and Goud (2010).

Stoloteuthis leucoptera- Würtz et al. (1995)

Stoloteuthis leucoptera - Sánchez et al. (1998)

Stoloteuthis leucoptera- Giordano and Carbonara (1999)

Stoloteuthis leucoptera- Biagi et al. (2002)

Stoloteuthis leucoptera-Cuccu et al. (2010)

Stoloteuthis leucoptera- Fanelli et al. (2012)

Stoloteuthis leucoptera- Quetglas et al. (2013)

Stoloteuthis leucoptera-Bello (2003 and references therein)

Stoloteuthis leucoptera - Zaragoza et al. (2015)

Stoloteuthis leucoptera- Keller et al. (2017)

Stoloteuthis leucoptera- Bello et al. (2020 and references therein).

\section{Diagnosis}

Stoloteuthis with a maximum size of $18 \mathrm{~mm}$ of mantle length; with a narrow occipital band; with a ventral shield of around $80 \%$ of the ventral mantle surface; with a wide head; tentacles representing 251-379\% of the mantle length; males with glands in the first two thirds of both dorsal and ventral margins of arms I; males with rows 2-4 of ventral suckers slightly enlarged, ventral, and dorsal rows 5-6 enlarged to the same level in arms II; males with 3-4 series of suckers at the tip of arms IV.
For a diagnosis of the genus Stoloteuthis see Verrill (1881, Appendix:417).

\section{Type Material}

Holotype. ICMC000164, mature male, $13.9 \mathrm{~mm}$ ML, 22 May 2006, $38.85783^{\circ} \mathrm{N} 0.98^{\circ} \mathrm{E}$, between 451 and $457 \mathrm{~m}$ depth. Paratypes: ICMC000165, mature male, $17.9 \mathrm{~mm} \mathrm{ML,} 22$ May 2006, $38.85783^{\circ} \mathrm{N} 0.98^{\circ} \mathrm{E}$, between 451 and $457 \mathrm{~m}$ depth; ICMC000163, mature female, $12.3 \mathrm{~mm}$ ML, 11 May 2006, $36.63767^{\circ} \mathrm{N} 2.45833^{\circ} \mathrm{W}$, between 324 and $326 \mathrm{~m}$ depth; ICMC000166, mature male, $16.7 \mathrm{~mm}$ ML, 25 May 2006, $40.1671667^{\circ} \mathrm{N} 0.7645^{\circ} \mathrm{E}$, between 77 and $81 \mathrm{~m}$ depth.

\section{Type Locality}

SW off Ibiza Island, Mediterranean Sea. $38.85783^{\circ} \mathrm{N}, 0.98^{\circ} \mathrm{E}$, between 451 and $457 \mathrm{~m}$ depth.

\section{Etymology}

The specific epithet cthulhui was erected in honor to the fiction cosmic horror entity "Cthulhu" created by Howard Phillips Lovecraft (1890-1937), which holds both cephalopodlike tentacles and wings (Lovecraft, 1928), resembling the pair of fins of this new species of butterfly squid. Cthulhu was described 


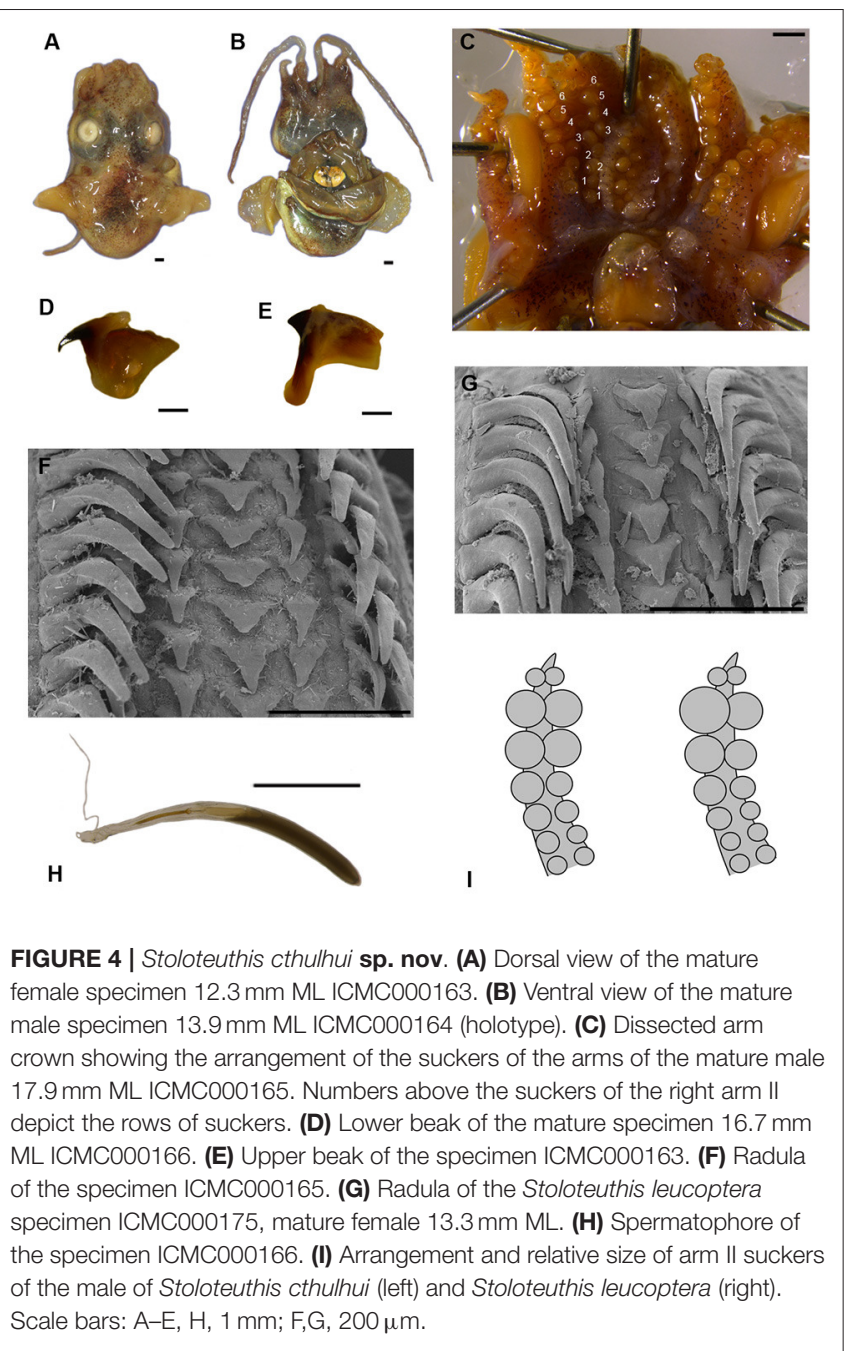

in the literature as male, so a male gender genitive suffix was applied. Pronunciation: /kə’ $\theta \mathrm{u}: \mathrm{lu}$ :/.

\section{Proposed Vernacular Names}

Cthulhu's butterfly squid (English), globito de Cthulhu (Spanish), morralet de Cthulhu (Catalan).

\section{Description}

Butterfly squid up to $18 \mathrm{~mm}$ DML (Figures 4A,B). The body is muscular with a rounded posterior end. The mantle dorsally is fused directly with the head forming a narrow commissure of 5$8 \mathrm{~mm}$ and is heavily and uniformly pigmented. Ventral mantle is anteriorly bilobed with roughly the same extension of dorsal mantle or slightly larger, with a ventral shield of dark brown pigment and an iridescent greenish hue roughly representing nearly $80 \%$ of the ventral mantle surface. This ventral shield is surrounded by a shallow yellowish bright band. Fins are large, oval, and less pigmented than the mantle, attached dorsally in the lateral mantle. The mantle component of the funnel/mantle locking-apparatus is straight with a low ridge at the mantle edge and the funnel component is a straight simple groove. The funnel reach the anterior edge of the eyes and the pigmentation forms a diamond patch from the funnel tip toward the mantle; near the tip of the funnel there is a round patch devoid of chromatophores, and the funnel sections covered by the lobes of the mantle also lack of chromatophores.

The head is bulbous, wide and uniformly pigmented, representing from 88 to $145 \%$ of the ML. Eyes are large and occupy most part of the head. Olfactory organs are prominent. Arms are short and muscular with a well-developed keel in arms III. Arm formula: II $\approx$ III $>$ I $>$ IV. Two rows of suckers in both arms, but in males the arms IV might appear to have four rows. Female arm crown lacks of any enlarged suckers. Arm suckers in all arms more developed in males than in females. Arms I of mature males with well-developed glands in the first two thirds of both dorsal and ventral margins. Arms II suckers from rows 2-6 are slightly enlarged according with the following pattern: rows $2-4$ of ventral suckers are slightly enlarged and the ventral and dorsal rows 5-6 have the same degree of enlargement (Figure 4C). A well-developed web unites the arms until approximately the last third of the arm length from arms I-III, arms IV united by a shallower web reaching less than a quarter of the arm length or absent (individual ICMC000165). Tentacles range from 44 to $46 \mathrm{~mm}$ length, representing $251-379 \%$ of ML. The distal 5-6 mm of the tentacles are occupied by the club. The tentacle organ slightly overlaps the tentacle club, formed by 10-11 transversal rows of suckers, which are larger in both proximal and terminal rows of the club.

The light organ has the typical shape for Heteroteuthinae (Figure 4B), with a round morphology and two pores in the midline. The visceral mass was not dissected. The upper beak has a long and curved rostrum of $0.8-0.9 \mathrm{~mm}$ length with a sharp pointed rostral tip (Figure 4D), representing $\sim 4.9 \%$ of the ML. Beak angle of $\sim 90^{\circ}$, with a smooth edge; specimen ICMC000165 has an irregular tooth. Hood is small and fragile. The rostrum and the shoulders are darkly pigmented, while the hood and the lateral wings are moderately pigmented. Lower beak has a short and blunt rostrum of $0.6-0.7 \mathrm{~mm}$ length with a rounded rostral tip (Figure 4E), representing $\sim 3.6-3.7 \%$ of the ML. The lower beak angle is of $\sim 130^{\circ}$, without teeth. The hood is narrow and the wings are wide. The rostrum and the hood are darkly pigmented, while the wings and lateral walls are moderately pigmented and almost transparent at the edges. The male specimens ICMC000165 and ICMC000166 and the female specimen ICMC000165, 17.9, 16.7, and $12.3 \mathrm{~mm} \mathrm{ML}$, respectively, were used for measuring the radulae. The radula has seven transverse rows of teeth displaying a typical homodont morphology (Figure 4F). Rhachidean teeth are 96-126 $\mathrm{m}$ length, with a wide base, sharply pointed and slightly curved shape. First lateral teeth are $88-130 \mu \mathrm{m}$ length, with a narrower base, sharply pointed and slightly curved shape. The second lateral and marginal teeth are narrow and strongly curved, of $98-164 \mu \mathrm{m}$ and 176-240 $\mu \mathrm{m}$ length, respectively. All the spermatophores of specimens ICMC000165 and ICMC000166 were extracted and counted, and a random selection of 30 were used for measuring their length. ICMC000165, $17.9 \mathrm{~mm} \mathrm{ML}$, had 236 spermatophores of $2.6 \pm 0.1 \mathrm{~mm}$ length (range $2.5-3.0 \mathrm{~mm}$ ). 
TABLE 5 | Measurements (in $\mathrm{mm}$ ) of the type material of Stoloteuthis cthulhui sp. nov.

\begin{tabular}{|c|c|c|c|c|}
\hline \multirow[t]{2}{*}{ Character } & \multicolumn{4}{|c|}{ Individual } \\
\hline & ICMC000163 & $\begin{array}{c}\text { ICMC000164 } \\
\text { (holotype) }\end{array}$ & ICMC000165 & ICMC000166 \\
\hline Sex & Female & Male & Male & Male \\
\hline DML & 12.3 & 13.9 & 17.9 & 16.7 \\
\hline VML & 19.4 & 13 & 16.3 & - \\
\hline FW & 32.4 & 21.2 & 32 & 23.1 \\
\hline $\mathrm{FL}$ & 10.1 & 9.8 & 8 & 9 \\
\hline FB & 6.5 & 6 & 6.8 & 9 \\
\hline $\mathrm{OBL}$ & 7.6 & 6.8 & 4.9 & 10.3 \\
\hline VSL & - & 10.3 & 15 & - \\
\hline HW & 17.8 & 12.3 & 17.2 & 16.8 \\
\hline HL & 9.8 & 12 & 12.7 & 10.3 \\
\hline FnL & 9.4 & 7.2 & 8.6 & 7.9 \\
\hline AlL & 6.8 & 7.5 & 6.8 & 7.2 \\
\hline AllL & 8.2 & 8.4 & 8.6 & 7.8 \\
\hline AllIL & 9.3 & 7.5 & 8.2 & 9.7 \\
\hline AIVL & 7.6 & 5.6 & 7 & 7.3 \\
\hline TeL & 46.5 & 46 & 44.9 & 46.4 \\
\hline $\mathrm{CL}$ & 6.6 & 5.4 & 4.6 & 5.8 \\
\hline WDA & 4 & 3.7 & 2.9 & 5.4 \\
\hline WDB & 2.9 & 3.9 & 3.6 & 4.7 \\
\hline WDC & 3.3 & 2.8 & 4.6 & 4.2 \\
\hline WDD & 3.7 & 3.2 & 2.6 & - \\
\hline WDE & 2.3 & 1.2 & - & 0 \\
\hline URL & 0.88 & - & 0.88 & 0.82 \\
\hline LRL & 0.74 & - & 0.66 & 0.61 \\
\hline $\mathrm{SpC}$ & N/A & - & 236 & 11,645 \\
\hline SpL & N/A & - & $2.6 \pm 0.1$ & $1.9 \pm 0.2$ \\
\hline $\mathrm{SpH}$ & $\mathrm{N} / \mathrm{A}$ & - & $0.28 \pm 0.01$ & - \\
\hline SpE & N/A & - & $0.76 \pm 0.03$ & - \\
\hline SpCe & N/A & - & $0.64 \pm 0.05$ & - \\
\hline SpS & N/A & - & $1.32 \pm 0.05$ & - \\
\hline SpEm & N/A & - & $0.0 \pm 0.0$ & - \\
\hline
\end{tabular}

DML, dorsal mantle length; VML, ventral mantle length; FW, fin width; FL, fin length; FB, fin base; OBL, head occipital band lenght; VSL, ventral shield length; HW, head width; HL, head length; FnL, funnel length; AIL-AIVL, arm I-IV length; TeL, tentacle length; CL, tentacle club length; WDA-E, web depth A-E; URL, upper beak rostral length; LRL, lower beak rostral length; SpC, spermatophore count; SpL, spermatophore length index; SpH, spermatophore head; SpE, spermatophore ejaculatory tube; SpCe, spermatophore cement body;

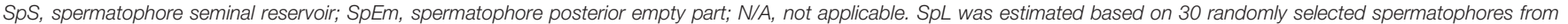

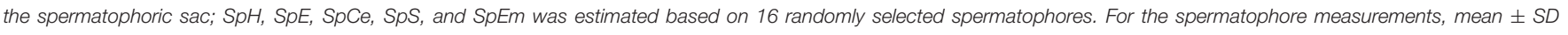
are indicated.

Spermatophores were intact and the spermatophoric reaction was not triggered (Figure 4H). Spermatophore threads were short and in most cases they were broken. Spermatophores head measures $0.28 \pm 0.01 \mathrm{~mm}$ and holds three loops of the ejaculatory ducts. The ejaculatory apparatus is $0.76 \pm$ $0.03 \mathrm{~mm}$ long and the spiral filament occupies $\sim 3 / 4$ of its length. The cement body is relatively long $(0.64 \pm 0.05 \mathrm{~mm})$ and approximately half of the length of spermatophore is occupied by the seminal reservoir $(1.32 \pm 0.05 \mathrm{~mm})$. There is no posterior empty part, but in those spermatophores fixed during the first steps of the spermatophoric reaction, a posterior empty part is observed. Specimen ICMC000166, $16.7 \mathrm{~mm} \mathrm{ML}$, had a strongly enlarged spermatophoric sac with a massive amount of spermatophores $(11,645)$ ranging from 1.4 to $2.4 \mathrm{~mm}$ length. Smaller spermatophores usually look similar to the larger ones, but with reduced seminal reservoirs. Other spermatophores of this specimen were empty and/or deformed and should be considered as tentative spermatophores sensu Nigmatullin et al. (2003).

\section{Distribution}

Western Mediterranean Sea. Some authors consider the presence of this species (cited as Sl. leucoptera) as a recent range expansion from Atlantic waters: see Bello et al. (2020) for a systematic review of these opinions. 


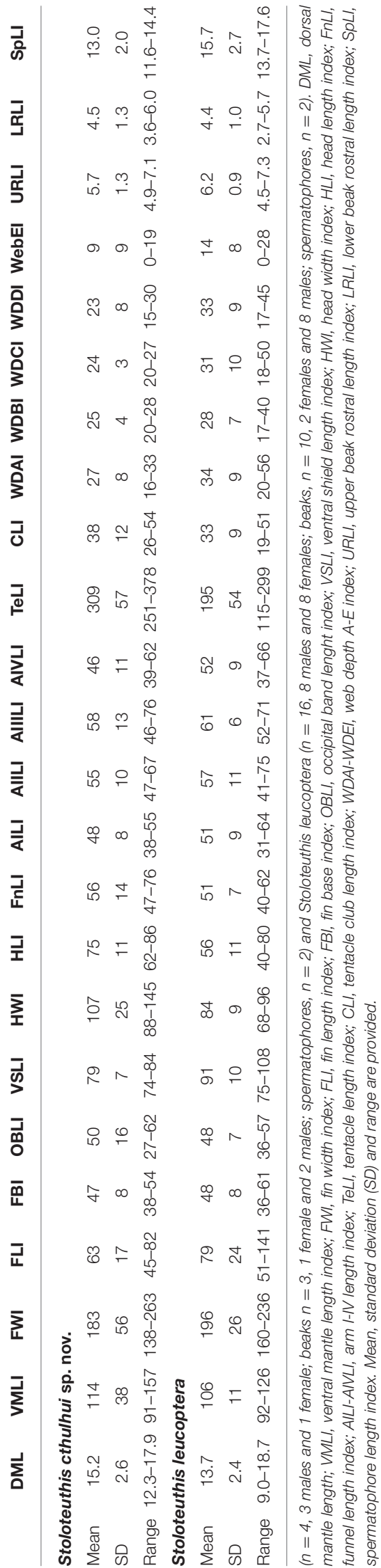

Molecular Data

The COI $p$-distances analyses (Tables 2, 3) show a $3.5 \%$ divergence between Sl. cthulhui sp. nov. and its sister species, Sl. leucoptera. This level of divergence was reported by Gebhardt and Knebelsberger (2015) and Groenenberg et al. (2009) between different closely-related bobtail squid species. Moreover, the same level of divergence was found between different well-established species in our analysis (Table 2).

\section{Remarks}

Morphological differences between Sl. cthulhui sp. nov. and Sl. leucoptera are subtle but still consistent. The morphology of the second pair of arms of the mature male differs in the assemblage of the enlarged suckers. In Sl. cthulhui sp. nov., the pattern is less evident than in Sl. leucoptera: the first row of suckers is unmodified, rows $2-4$ of ventral suckers are slightly enlarged and ventral and dorsal rows 5-6 of suckers showed the same level of enlargement, whereas in Sl. leucoptera, the first two rows of suckers are unmodified and ventral suckers from rows 3-6 are progressively enlarged (Figure 4I, see also Vecchione and Young, 2013). In some Sl. leucoptera specimens the fifth ventral sucker is larger than the sixth or dorsal suckers 5-6 might be larger than the ventral ones. Although the range of values overlaps in all cases, some differences also exist in some morphometric indexes (Table 6): the fin length and shield length are larger in Sl. leucoptera than in Sl. cthulhui sp. nov., while the head is narrower (68-96\% of ML) and the tentacles are shorter (115-299\% of ML). The rhachidean teeth of the Sl. leucoptera radulae are smaller, with $41-85 \mu \mathrm{m}$ length, measured in two mature females and two mature males 13.3-15.5 and 11.5$13.3 \mathrm{~mm} \mathrm{ML}$, respectively (Figure 4G). Although the remaining teeth of Sl. leucoptera also tend to be smaller, the length ranges overlap with Sl. cthulhui sp. nov. Other characters, such as other morphometric measures, the beaks morphology and the spermatophores did not show any other relevant morphological differences between the two species.

Stoloteuthis leucoptera was described in the Gulf of Maine, 30 miles east Cape Ann (North-western Atlantic Ocean) (Verrill, 1878). Previously to the present work, Sl. leucoptera was thought to be distributed in NW Atlantic Atlantic to Namibian and Mediterranean waters (Reid and Jereb, 2005; Vecchione and Young, 2013). We did not find any morphological differences between Namibian Sl. leucoptera (Villanueva and Sánchez, 1993; this work) and the descriptions from the literature for NW Atlantic Sl. leucoptera (e.g., Vecchione and Young, 2013). The individuals described by Orsi Relini and Massi (1991: Table 1) and Cuccu et al. (2010: Table 1) had a HWI of 105-130\%, consistent with Sl. cthulhui sp. nov. and not with Sl. leucoptera. We consider previous records of Mediterranean Sl. leucoptera as Sl. cthulhui sp. nov. (Orsi Relini and Massi, 1991; Volpi et al., 1995; Cuccu et al., 2010; Quetglas et al., 2013; Zaragoza et al., 2015).

\section{DISCUSSION}

All of the genera and twelve sepiolid species, covering $70 \%$ of the known specific biodiversity of the family in the Mediterranean 
Sea, have been barcoded and vouchered (Table 1). All the studied individuals were successfully linked with their taxonomic name and no inconsistencies arose among the newly sequenced material. Nevertheless, wrong identifications of bobtail squids are relatively frequent in GenBank, as previously reported by Groenenberg et al. (2009) and Sanchez et al. (2019). The work of Groenenberg et al. (2009) on DNA barcoding on vouchered individuals has solved some of the previously misidentified sequences. However, this work was based on animals from NE Atlantic waters and some species not studied by them remained unsolved. Here, we provided a correct barcode for many of these species, solving some of the previous problematic sequences (Table 4). Solving those problematic sequences based on morphologically identified animals is extremely important to ensure the quality of the identification based only on molecular data.

For most of the species studied here, there is a tendency of intraspecific distances below $2 \%$ and interspecific distances above $2.4-3 \%$ (Tables 2, 3). However, this pattern is not universal within the family and some exceptions occur. In fact, no clear barcode gap (Meyer and Paulay, 2005) was identified between intra- and interspecific distances, due to the presence of challenging groups, such as the clade formed by $S$. affinis, $S$. atlantica and S. intermedia. The interspecific distances of these three species are the smallest among our dataset (0.81$1.45 \%)$. In fact, the largest intraspecific p-distances among Sepiolinae (1.8\% in S. robusta and $2.3 \%$ in E. scolopes, Table 3 ) are larger than the interspecific distances between $S$. affinis, $S$. atlantica and $S$. intermedia, thus existing an overlapping between intra- and interspecific distances which complicates the use of DNA barcoding methods based on genetic distances for this group of animals. The three species have very distinctive hectocotylus morphology with discrete morphologies (Figure 3): the morphological variation of those species does not overlap (Bello, 1995; Reid and Jereb, 2005; de Heij and Goud, 2010). As far as we know, no hybrids have been described among them. While $S$. atlantica is allopatric in reference with the other two species, S. affinis and S. intermedia both occur in Mediterranean waters (Reid and Jereb, 2005), pointing out to the presence of effective reproductive isolation mechanisms acting at least between the two Mediterranean species. For this clade, only the single threshold approach of the GMYC among all the tested molecular species delimitation methods provided the same results as the morphology (Figure 3). If molecular identifications were carried out with no further morphological information, this level of interspecific distances might be mistaken as intraspecific variation. This low level of interspecific distances might be due to recent phenomena of speciation with a fast morphological drift of key morphological characters. Recently, Costa et al. (2021) found that two morphologically different species of coastal squids that diverged in recent times were recognized as a single species by molecular species delimitation methods. Their study and ours highlights the importance of combining studies based on molecular identifications with careful morphological examinations.

Another important phenomenon hindering the direct use of bobtail squid DNA sequences for species identifications is the presence of cryptic biodiversity. Although cryptic biodiversity is an increasingly reported phenomenon in cephalopod biodiversity studies (e.g., Anderson et al., 2007, Cheng et al., 2014, Fernández-Álvarez et al., 2020), this phenomenon is comparatively unknown in bobtail squids. This is especially true for E. hyllebergi and E. tasmanica, with interspecific distances between different OTUs ranging from 3.9 to $11.6 \%$. Remarkably, the two E. hyllebergi OTUs occur allopatrically in both Indian and Pacific coasts of the Thailand Peninsula, while E. tasmanica OTUs might occur sympatrically. It is known that the hatchling size and mode of life has an important effect on the distribution range of cephalopod species, since species with larger benthic hatchlings tend to have smaller distribution areas (Villanueva et al., 2016). Information on the way of life of bobtail squid during their first days of life is scarce (Villanueva et al., 2016: Tables 1,2). Available information points out that Rossinae and most Sepiolinae tend to have large benthic hatchlings, although some early stages of some species reported as benthic throughout their lives can be also be found in the water column (Olmos-Pérez et al., 2018b). It is particularly remarkable that the species with larger hatchlings from the subfamily Sepiolinae, E. tasmanica $(5 \mathrm{~mm}$ ML, Villanueva et al., 2016: Table 1), has more cryptic lineages with larger interspecific distances, accounting for four different OTUs with a divergence of $4.3-11.6 \%$ (Table 2). Interestingly, R. macrosoma has slightly larger benthic hatchlings $(5.5 \mathrm{~mm}$ $\mathrm{ML}$ ) and also has genetic structure, being taken as two species by several species delimitation methods. Comparisons between the sympatric geographic patterns of E. tasmanica lineages with the allopatric pattern found in Euprymna hyllebergi, a species with smaller planktonic hatchlings $(2.2 \mathrm{~mm} \mathrm{ML})$, suggest that large hatchlings with direct benthic development have a more intense effect on the dispersal capacity and communication between distant cephalopod populations, and it might be one of the triggers that increase the opportunities for speciation. Rossinae are mostly exclusively benthic species, and Sepiolinae usually are usually reported as benthic species (Reid and Jereb, 2005), but they can also be found in the water column (Bello and Biagi, 1995). Absence of ontogenetic migrations have been suggested for some Sepiolinae species (e.g., Villanueva, 1995), which suggests that this restrictions to movement limit dispersal, contributing to slow down the gene flow between distant populations. This putative lower dispersal during both young and adult stages combined by the fact that some species inhabit relatively non-overlapping bathymetric ranges might have helped to trigger speciation in the Mediterranean Sea and increase their endemic bobtail species (Bello, 2019). Bobtail squids are among the cephalopods with higher tolerances to salinity changes (Mangold and Boletzky, 1988) and young stages can be found in estuarine systems (e.g., Olmos-Pérez et al., 2018b), and adults in the intertidal regions (Fernández-Álvarez, pers. obs.). Thus, it seems that salinity it is not a great limitation to bobtail squid dispersal. The Mediterranean Sea Sepiolinae fauna is characterized by the high number of endemic species (Bello, 2019), while many Atlantic species does not distribute also in the Mediterranean. It is possible that the effect of some well-known oceanographic barriers to genetic exchange, such as the Strait of Gibraltar (Pascual et al., 2017), had an important 
effect on the evolutionary history and current distribution of European Sepiolinae, while the differences in salinity between the Mediterranean and the Atlantic (Mangold and Boletzky, 1988) might have a comparatively smaller effect. Future population genetic studies focused on those species can answer this question.

Members of the subfamily Heteroteuthinae are exclusively nektonic and benthic-pelagic species (e.g., Orsi-Relini, 1995). Although it is known that oceanic currents can isolate populations of some pelagic squids and lead them to speciation (e.g., Fernández-Álvarez et al., 2020), the opportunities to dispersal and population connectivity are comparatively larger in oceanic environments than in shallow benthic ecosystems. Thus, large distribution areas on wide oceanic basins are commonly reported in Heteroteuthinae species (Reid and Jereb, 2005). According with Vecchione and Young (2007), there are no known morphological differences between $H$. dispar and $H$. hawaiinensis, while all the molecular species delimitation methods performed here support their treatment as different species. In the absence of known morphological differences, these two species shall be considered as members of a cryptic species complex. A third undescribed species with a not yet described morphology, Heteroteuthis sp. KER (Braid and Bolstad, 2019), form a clade with $H$. dispar and $H$. hawaiinensis. Heteroteuthis dagamensis have a large distribution ranging from the Gulf of Mexico and the South Atlantic (Judkins et al., 2016) to New Zealand (Braid and Bolstad, 2019) and North Atlantic (Taite et al., 2020). Four out six of the molecular species delimitation analyses recognized cryptic biodiversity within this species (Figure 3). The large distribution range of the species in combination with the large intraspecific divergence between New Zealand and the specimens coming from other latitudes ( $>2 \%$, Table 3 ) suggests that some processes of speciation in its early stage might be taking place. Between those described cryptic Heteroteuthis species (H. dispar and $H$. hawaiinensis), undescribed new species (Heteroteuthis sp. KER) and cryptic lineages ( $H$. dagamensis) some well-known oceanic and terrestrial barriers exists, such as the Panama Isthmus and the currents that creates the main oceanographic gyres. New combined morphological and molecular studies are necessary for solving this taxonomic problem.

It is remarkable the fact that a closer relationship exists between Sl. japonica and Se. nipponensis (2.4\%) rather than between Sl. japonica and other congeneric species (12.7\% with Sl. cthulhui sp. nov. and $14.3 \%$ with Sl. leucoptera). Divergence between Sepiolina petasus Kubodera and Okutani, 2011 and Se. nipponensis is $13.9 \%$, similar to that reported between species of the genera Sepiolina and Heteroteuthis. These data suggest that the current generic assignations to genera in Heteroteuthinae species are not fully molecularly supported and should be revised in future combined morphological and molecular studies, as already suggested by Allcock et al. (2014).

All molecular species delimitation analyses consistently identified Sl. leucoptera and Sl. cthulhui sp. nov. as different species (Figure 3), also the COI divergence of 3.5\% is typical for different species in bobtail squids. This difference is consistent with interspecific levels in many other invertebrates, such as nemerteans (Fernández-Âlvarez and Machordom, 2013), land planarians (Lago-Barcia et al., 2015), crustaceans (Robles et al., 2007), and other cephalopods (Gebhardt and Knebelsberger, 2015; Fernández-Álvarez et al., 2020). Besides, the morphological comparisons between Sl. leucoptera and Sl. cthulhui sp. nov. showed a few differences in key morphological characters that until now remained overlooked, such as the length of the tentacle, the width of the head and slight differences in the sexual modifications of arm II in mature males. In general, it seems that the modifications of the arm II in Sl. cthulhui sp. nov. are less pronounced than in Sl. leucoptera. Even so, the differences between both species are few, likely representing a shallow morphological drift and a recent speciation phenomenon. Species involved in those first steps are commonly referred as in the "gray speciation zone" (Roux et al., 2016). As we showed with S. affinis, S. atlantica and S. intermedia, as well as the molecular data provided for the descriptions of Sl. japonica and Sp. nipponensis, these situations are likely to be frequent in bobtail squids. Based on this observation, the specific status of distant populations with mild levels of genetic divergence, which are typically identified as intraspecific levels of divergence, should be taken with care.

We took special care of including as many morphological characters as possible to avoid overlooking possible morphological differences between the congeneric Sl. cthulhui sp. nov. and Sl. leucoptera. That is the case of beak and radulae morphologies, which are rarely used in bobtail squid taxonomy (e.g., Kubodera and Okutani, 2011; Sanchez et al., 2019), and spermatophores. The use of spermatophores in cephalopod taxonomy should be taken with caution, as our study also shows. It is known that spermatophore size depends on the size of the male that produces it and since they can accumulate spermatophores for long periods of time, the same individual can hold spermatophores of a huge range of sizes and morphologies, according with the somatic size of the squid when each spermatophore was formed (Hoving et al., 2010; Cuccu et al., 2014). The number of spermatophores stored by the male would vary according with when it mated the last time (if anything at all) and so will do the size of those structures. In the present study we found 353-358 spermatophores in the spermatophoric sacs of Sl. leucoptera, while 236 (ICMC000165) and 11,645 (ICMC000166) spermatophores were found in the two examined specimens of Sl. cthulhui sp. nov. It is interesting to point the fact that the specimen ICMC000165, with a lower number of spermatophores, was also the same individual with a narrowest range of spermatophore size. Particularly, the specimen ICMC000166 not only showed the largest range of spermatophore size: it also showed empty and aberrant spermatophores. It is known that in the beginning of their reproductive life, cephalopod males produce tentative spermatophores (Nigmatullin et al., 2003) and in this case both functional and tentative spermatophores were present in the spermatophoric sac. It is not known to us if this was related with the absence of mating events by this individual for any circumstance or if it is just an aberrant individual. Pelagic cephalopods might have difficulties to find conspecifics to mate (Hoving et al., 2012), or just the opposite situation (Fernández-Álvarez et al., 2018; Hoving et al., 2019), so species 
with promiscuous mating systems are expected to hold a less variable morphology in the spermatophores stored in the spermatophoric sac. Special attention should be taken to the characteristics of a cephalopod species sex life if spermatophores are going to be used as a taxonomic character.

\section{CONCLUSIONS}

In this study we provided new sequence data for most of the Mediterranean bobtail squid species and added other relevant sequence data from species from other parts of the world. The combined use of several molecular species delimitation methods consistently showed a picture of hidden biodiversity. On the one hand, most of those methods failed to accurately assess the actual biodiversity of some morphologically different species, hindering the use of molecular data for species identification in the absence of morphological data. On the other hand, cryptic biodiversity was detected among members of the same nominal species, pointing to the fact that in some cases, speciation phenomena might be occurring without a parallel morphological evolution. It is also possible that the comparatively low number of taxonomists working on bobtail squids has hindered the discovery of morphological differences between them or that some morphological differences had been overlooked, as it happened with the new Stoloteuthis species described in this work. The Mediterranean Sea is one of the more diverse and the better studied areas for members of the family Sepiolidae, with a literature production spanning through more than a century (Bello, 2015). Despite this intense biodiversity and taxonomic research, two new Mediterranean species were described in the last few years (Bello, 2013; Bello and Salman, 2015). Here, a new species of Mediterranean Stoloteuthis, previously misidentified, was discovered and described, both using molecular and morphological methods. It is also remarkably that Olmos-Pérez et al. (2018b) found a species ("Heteroteuthinidae" sp.) in European waters whose sequences cannot be assigned to any sequenced species of bobtail squid, while Sanchez et al. (2019) discovered two new species of the genus Euprymna in Pacific waters. All these recent new species discoveries stress the need of new taxonomic studies in both benthic and pelagic bobtail squids on a worldwide basis.

\section{DATA AVAILABILITY STATEMENT}

The datasets presented in this study can be found in online repositories. The names of the repository/repositories and accession number(s) can be found at: NCBI GenBank (accession: MW260131-MW260134).

\section{ETHICS STATEMENT}

Ethical review and approval was not required for the animal study because the cephalopods we worked with for this study were all dead before research began.

\section{AUTHOR CONTRIBUTIONS}

FÁF-Á, PS, and RV conceived the study, participate in sample collection and identification, and performed morphological examinations. FÁF-Á performed the phylogenetic analyses, data curation, and prepared the first draft. All authors contributed to the manuscript preparation and revision and read and approved the submitted version.

\section{FUNDING}

FÁF-Á was supported by an Irish Research CouncilGovernment of Ireland Post-doctoral Fellowship Award (Ref. GOIPD/2019/460) and by a predoctoral fellowship of the Spanish Ministry of Economy and Competitiveness (MINECO, BES-2013-063551). Some specimens were collected on board the RV Hespérides during the research project MAFIA (CTM201239587-C04-03), funded by the MINECO (FEDER/EU), and on board the RV García de Cid during the research cruise FORMED (CGL2012-33989, MINECO). This study was partially funded by the Spanish Ministry of Science, Innovation and Universities (OCTOSET project, RTI2018-097908-B-I00, MCIU/AEI/FEDER, EU) and the European Commission (SUMMER project, GA-817806).

\section{ACKNOWLEDGMENTS}

We thank Nuria Zaragoza, Alfredo García de Vinuesa, Anabel Colmenero (ICM-CSIC) and the crew of the fishing trawlers Peret de Fava (Tarragona) and La Seu (Vilanova i la Geltrú) for collecting samples. Thanks to Elisabeth Cuesta-Torralvo (University of Barcelona), Catarina P. P. Martins (Justus Liebig University of Giessen) and Oscar Escolar (ICM-CSIC) for assistance in the lab. Thanks to Mr. J. M. Fortuño (Electron Microscopy Service, ICM-CSIC) for his dedication and kindness during the SEM sessions. Elena Guerrero (ICMCSIC) performed the curation of the morphological vouchers under the CBR-ICM. We thank the two reviewers for their helpful comments. DNA extractions, PCRs, and sequencing were performed in AllGenetics (A Coruña, Spain). We thank Ate de Heij and Jeroen Goud for granting permission to use the Sepiola atlantica hectocotylus drawing by Bas Blankevoort (Naturalis, Netherlands).

\section{REFERENCES}

Allcock, A. L., Lindgren, A., and Strugnell, J. M. (2014). The contribution of molecular data to our understanding of cephalopod evolution and systematics: a review. J. Nat. His. 49, 1373-1421. doi: 10.1080/00222933.2013. 825342

Anderson, F. E., Valinassab, T., Ho, C. W., Mohamed, K. S., Asokan, P. K., Rao, G. S., et al. (2007). Phylogeography of the pharaoh cuttle Sepia pharaonis based on partial mitochondrial 16S sequence data. Rev. Fish Biol. Fisher. 17, 345-352. doi: $10.1007 / \mathrm{s} 11160-007-9042-1$

Appellöf, A. (1898). Cephalopoden von Ternate, 2: untersuchung genuber Idiosepius, Sepiadarium und verwandte Formen, ein Beitrag zur Beleuchtung 
der Hektokotylisation und ihrer systematischen Bedeutung. Abh. Senckenb. Naturforsch. Ges. 24, 570-637.

Bello, G. (1995). A key for the identification of the Mediterranean sepiolids (Mollusca: Cephalopoda). Bull. Inst. Océanogr. 16, 41-56.

Bello, G. (2003). The biogeography of Mediterranean cephalopods. Biogeographia 24, 209-226. doi: 10.21426/B6110092

Bello, G. (2013). Description of a new sepioline species, Sepiola bursadhaesa sp. nov. (Cephalopoda: Sepiolidae), from the Catalan Sea, with remarks and identification key for the Sepiola atlantica group. Sci. Mar. 77, 489-499. doi: $10.3989 /$ scimar.03720.31A

Bello, G. (2015). The original descriptions of the Mediterranean taxa in the order Sepiolida (Mollusca: Cephalopoda) with notes on the validity of the specific name Sepiola rondeletii Leach, 1817. Boll. Malacol. 51, 22-46.

Bello, G. (2019). The Mediterranean Sepiolidae (Mollusca Cephalopoda) diversity. Biodivers. J. 10, 389-404. doi: 10.31396/Biodiv.Jour.2019.10.4.389.404

Bello, G. (2020). Evolution of the hectocotylus in Sepiolinae (Cephalopoda: Sepiolidae) and description of four new genera. Eur. J. Taxon. 655, 1-53. doi: 10.5852/ejt.2020.655

Bello, G., Andaloro, F., and Battaglia,. P. (2020). Non-indigenous cephalopods in the Mediterranean Sea: a review. Acta Adriat. 61, 113-134.

Bello, G., and Biagi, V. (1995). How benthic are sepiolids? Bull. Inst. Océanogr. $16,97-61$.

Bello, G., and Salman, A. (2015). Description of a new sepioline species, Sepiola boletzkyi sp. nov. (Cephalopoda: Sepiolidae), from the Aegean Sea. Eur. J. Taxon. 144, 1-12. doi: 10.5852/ejt.2015.144

Berry, S. S. (1909). Diagnoses of new cephalopods from the Hawaiian Islands. Proc. U. S. Natl. Mus. 37, 407-419. doi: 10.5479/si.00963801.37-1713.407

Berry, S. S. (1911). A new sepiolid from Japan. Zool. Anz. 37, 39-41.

Berry, S. S. (1913). Some new Hawaiian cephalopods. Proc. U. S. Natl. Mus. 45, 563-566. doi: 10.5479/si.00963801.1996.563

Biagi, F., Sartor, P., Ardizzone, G. D., Belcari, P., Belluscio, A., and Serena, F. (2002). Analysis of demersal fish assemblages of the Tuscany and Latium coasts (north-western Mediterranean). Sci. Mar. 66, 233-242. doi: $10.3989 /$ scimar.2002.66s 2233

Bond, J., and Stockman, A. (2008). An integrative method for delimiting cohesion species: finding the population-species interface in a group of Californian trapdoor spiders with extreme genetic divergence and geographic structuring. Syst. Biol. 57, 628-646. doi: 10.1080/106351508023 02443

Braid, H. E., and Bolstad, K. S. R. (2019). Cephalopod biodiversity of the Kermadec Islands: implications for conservation and some future taxonomic priorities. Invertebr. Syst. 33, 402-425. doi: 10.1071/IS18041

Carlini, D., and Graves, J. E. (1999). Phylogenetic analysis of cytochrome c oxidase i sequences to determine higher-level relationships within the coleoid cephalopods. Bull. Mar. Sci. 64, 57-76.

Cheng, S. H., Anderson, F. E., Bergman, A., Mahardika, G. N., Muchlisin, Z. A., Dang, B. T., et al. (2014). Molecular evidence for co-occurring cryptic lineages within the Sepioteuthis cf. lessoniana species complex in the Indian and Indo-West Pacific Oceans. Hydrobiologia 725, 165-188. doi: 10.1007/s10750-013-1778-0

Clarke, M. R. (1986). A Handbook for the Identification of Cephalopod Beaks. Oxford: Clarendon Press.

Clement, M., Posada, D., and Crandall, K. (2000). TCS: a computer program to estimate gene genealogies. Mol. Ecol. 9, 1657-1660. doi: 10.1046/j.1365-294x.2000.01020.x

Costa, T. A. S., Sales, J. B. L., Markaida, U., Granados-Amores, J., Gales, S. M., Sampaio, I., et al. (2021). Revisiting the phylogeny of the genus Lolliguncula Steenstrup 1881 improves understanding of their biogeography and proves the validity of Lolliguncula argus Brakoniecki \& Roper, 1985. Mol. Phylogenet. Evol. 154:106968. doi: 10.1016/j.ympev.2020.106968

Cuccu, D., Mereu, M., Agus, B., Cau, A., Culurgioni, J., Sabatini, A., et al. (2014). Male reproductive system and spermatophores production and storage in Histioteuthis bonnellii (Cephalopoda: Histioteuthidae): a look into deep-sea squids? reproductive strategy. Deep Sea Res. 91, 86-93. doi: 10.1016/j.dsr.2014.05.016

Cuccu, D., Mereu, M., Masala, P., Cau, A., and Jereb, P. (2010). First record of Stoloteuthis leucoptera (Cephalopoda: Sepiolidae) in the Sardinian waters. Biol. Mar. Mediterr. 17, 334-335.
Férussac, A. E., and d'Orbigny, A. (1834-1848). Histoire Naturelle Générale et Particulière des Céphalopodes Acétabulifères Vivants et Fossiles. Paris: J. B. Balliere. doi: 10.5962/bhl.title.156830

de Heij, A., and Goud, J. (2010). Sepiola tridens spec. nov., an overlooked species (Cephalopoda, Sepiolidae) living in the North Sea and north-eastern Atlantic Ocean. Basteria 74, 51-62.

delle Chiaje, S. (1830). Memorie Sulla Storia e Notomia Degli Animali Senza Vertebre del Regno di Napoli. Naples: Società Tipografica.

Demestre, M., Muntadas, A., Duran, R., García-de-Vinuesa, A., Sánchez, P., Mas, J., et al. (2017). "Characterization of benthic communities in a subaqueous dune field on the continental shelf (Mar Menor, Western Mediterranean)," in Atlas of Bedforms in the Western Mediterranean, eds J. Guillén, J. Acosta, F. Chiocci, and A. Palanques (Cham: Springer International Publishing), 207-214. doi: 10.1007/978-3-319-33940-5_32

Drummond, A. J., and Rambaut, A. (2007). BEAST: Bayesian evolutionary analysis by sampling trees. BMC Evol. Biol. 7:214. doi: 10.1186/1471-2148-7-214

Fanelli, E., Cartes, J. E., and Papiol, V. (2012). Assemblage structure and trophic ecology of deep sea demersal cephalopods in the Balearic basin (NW Mediterranean). Mar. Freshw. Res. 63, 264-274. doi: 10.1071/MF11157

Fernández-Álvarez, F. Á., Braid, H. E., Nigmatullin, C. M., Bolstad, K. S. R., Haimovici, M., Sánchez, P., et al. (2020). Global biodiversity of the genus Ommastrephes d'Orbigny, 1834 (Ommastrephidae: Cephalopoda): an allopatric cryptic species complex. Zool. J. Linn. Soc. 190, 460-482. doi: 10.1093/zoolinnean/zlaa014

Fernández-Álvarez, F. Á., Li, D. H., Portner, E., Villanueva, R., and Gilly, W. F. (2017). Morphological description of egg masses and hatchlings of Lolliguncula diomedeae (Cephalopoda: Loliginidae). J. Molluscan Stud. 83, 194-199. doi: 10.1093/mollus/eyx008

Fernández-Álvarez, F. Á., and Machordom, A. (2013). DNA barcoding reveals a cryptic nemertean invasion in Atlantic and Mediterranean waters. Helgol. Mar. Res. 67, 599-605. doi: 10.1007/s10152-013-0346-3

Fernández-Álvarez, F. Á., Villanueva, R., Hoving, H. J. T., and Gilly, W. F. (2018). The journey of squid sperm. Rev. Fish Biol. Fish. 28, 191-199. doi: 10.1007/s11160-017-9498-6

Fischer, P. (1880-1887). Manuel de Conchyliologie et de Paléontologie Conchyliologique ou Histoire Naturelle des Mollusques Vivants et Fossils. Paris: Librairie F. Savy. doi: 10.5962/bhl.title.13213

Folmer, O., Black, M., Hoeh, W., Lutz, R., and Vrijenhoek, R. (1994). DNA primers for amplification of mitochondrial cytochrome c oxidase subunit I from diverse metazoan invertebrates. Mol. Mar. Biol. Biotechnol. 3, 294-299.

Fujisawa, T., and Barraclough, T. G. (2013). Delimiting species using singlelocus data and the generalized mixed yule coalescent approach: a revised method and evaluation on simulated data sets. Syst. Biol. 62, 707-724. doi: $10.1093 /$ sysbio/syt033

Gebhardt, K., and Knebelsberger, T. (2015). Identification of cephalopod species from the North and Baltic Seas using morphology, COI and 18S rDNA sequences. Helgol. Mar. Res. 69, 259-271. doi: 10.1007/s10152-015-0434-7

Giordano, D., and Carbonara, P. (1999). Nota sulla distribuzione di molluschi cefalopodi nel Tirreno Centro-Meridionale. Biol. Mar. Medit. 6, 573-575.

Grimpe, G. (1921). Teuthologische Mitteilungen VIII. Die Sepiolinen der Nordsee. Zool. Anz. 53, 1-12.

Groenenberg, D. S. J., Goud, J., de Heij, A., and Gittenberger, E. (2009). Molecular phylogeny of North Sea Sepiolinae (Cephalopoda: Sepiolidae) reveals an overlooked Sepiola species. J. Molluscan Stud. 75, 361-369. doi: 10.1093/mollus/eyp032

Guerrero, E., Abelló, P., Lombarte, A., Villanueva, R., Ramón, M., Sabatés, A., et al. (2020). Biological Reference Collections ICM-CSIC. v1.28. Institute of Marine Sciences (ICM-CSIC). Dataset/Occurrence. Available online at: https://doi.org/ 10.15470/qlqqdx (accessed December 30, 2020).

Hart, M. W., and Sunday, J. (2007). Things fall apart: biological species form unconnected parsimony networks. Biol. Lett. 3, 509-512. doi: $10.1098 / \mathrm{rsbl} .2007 .0307$

Hebert, P. D., Cywinska, A., and Ball, S. L. (2003). Biological identifications through DNA barcodes. Proc. R. Soc. B, 270, 313-321. doi: $10.1098 /$ rspb.2002.2218

Hoving, H.-J. T., Bush, S. L., and Robison, B. H. (2012). A shot in the dark: same sex sexual behaviour in a deep-sea squid. Biol. Lett. 8, 287-290. doi: $10.1098 / \mathrm{rsbl} .2011 .0680$ 
Hoving, H.-J. T., Fernández-Álvarez, F. Á., Portner, E. J., and Gilly, W. F. (2019). Same-sex sexual behaviour in an oceanic squid, ommastrephid Dosidicus gigas (Humboldt squid). Mar. Biol. 166:33. doi: 10.1007/s00227-019-3476-6

Hoving, H. J. T., Lipinski, M. R., and Dam, L. (2010). The male reproductive strategy of a deep-sea squid: sperm allocation, continuous production, and long-term storage of spermatophores in Histioteuthis miranda. ICES J. Mar. Sci. 67, 1478-1486. doi: 10.1093/icesjms/fsq041

International Commission on Zoological Nomenclature. (1999). International Code of Zoological Nomenclature. 4th Edn. London: International Trust for Zoological Nomenclature.

Jones, B. W., Lopez, J. E., Huttenburg, J., and Nishiguchi, M. K. (2006). Population structure between environmentally transmitted vibrios and bobtail squids using nested clade analysis. Mol. Ecol. 15:4317. doi: 10.1111/j.1365-294X.2006.03073.x

Joubin, L. (1902). Observations sur divers Céphalopodes, sixième note: Sur une nouvelle espèce du genre Rossia. Bull. Soc. Zool. France 27, 138-143.

Judkins, H. L., Vecchione, M., and Rosario, K. (2016). Morphological and molecular evidence of Heteroteuthis dagamensis in the Gulf of Mexico. Bull. Mar. Sci. 92, 51-57. doi: 10.5343/bms.2015.1061

Kang, X.-X., Fernández-Álvarez, F. Á., Alfaya, J. E. F., Machordom, A., Strand, M., Sundberg, P., et al. (2015). Species diversity of Ramphogordius sanguineus/Lineus ruber-like nemerteans (Nemertea: Heteronemertea) and geographic distribution of $R$. sanguineus. Zool. Sci. 32, 579-589. doi: 10.2108/zs150064

Keller, S., Hidalgo, M., Álvarez-Berastegui, D., Bitetto, I., Casciaro, L., Cuccu, D., et al. (2017). Demersal cephalopod communities in the Mediterranean: a largescale analysis. Mar. Ecol. Progr. Ser. 584, 105-118. doi: 10.3354/meps 12342

Kubodera, T. and Okutani, T. (2011). New additions of luminous bobtail squids to the Japanese cephalopod fauna (Sepiolida: Sepiolidae: Heteroteuthinae). Venus 69, 145-161. doi: 10.18941/venus.69.3-4_145

Kubodera, T., Okutani, T., and Kosuge, T. (2009). A new bobtail squid ex-pisce form Yonaguni Island, southwestern Japan (Cephalopoda: Sepiolidae). Venus $67,173-179$

Lago-Barcia, D., Fernández-Álvarez, F. Á., Negrete, L., Brusa, F., Damborenea, C., Grande, C., et al. (2015). Morphology and DNA barcodes reveal the presence of the non-native land planarian Obama marmorata (Platyhelminthes, Geoplanidae) in Europe. Invertebr. Syst. 29, 12-22. doi: 10.1071/IS14033

Leach, W. E. (1817). Synopsis of the orders, families, and genera of the class Cephalopoda. Zool. Miscell. 3, 137-141.

Lindgren, A. R., Giribet, G., and Nishiguchi, M. K. (2004). A combined approach to the phylogeny of Cephalopoda (Mollusca). Cladistics 20, 454-486. doi: 10.1111/j.1096-0031.2004.00032.x

Lleonart, J., Demestre, M., Martín, P., Rodón, J., Sainz-Trápaga, S., Sánchez, P., et al. (2014). The co-management of the sand eel fishery of Catalonia (NW Mediterranean): the story of a process. Sci. Mar. 78, 87-93. doi: $10.3989 /$ scimar.04027.25A

Lovecraft, H. P. (1928). The call of Cthulhu. Weird Tales, XI, 159-178.

Mangold, K., and Boletzky, S. V. (1988). "Mediterranean cephalopod fauna," in The Mollusca. Vol. 12, eds M. R. Clarke and E. R. Trueman (London: Academic Press), 315-330. doi: 10.1016/B978-0-12-751412-3.50025-5

Marian, J. E. A. R. (2015). Evolution of spermatophore transfer mechanisms in cephalopods. J. Nat. His. 49, 1423-1455. doi: 10.1080/00222933.2013.825026

Meyer, C. P., and Paulay, G. (2005). DNA barcoding: error rates based on comprehensive sampling. PLoS Biol. 3, 2229-2238. doi: 10.1371/journal.pbio.0030422

Miller, M. A., Pfeiffer, W., and Schwartz, T. (2010). "Creating the CIPRES Science Gateway for inference of large phylogenetic trees," in Proceedings of the Gateway Computing Environments Workshop (GCE) (New Orleans, LA), 1-8. doi: 10.1109/GCE.2010.5676129

Naef, A. (1912a). Teuthologische Notizen. 1. Die Familien der Myopsiden; 2. Die Gattungen der Sepioliden. Zool. Anz. 39, 241-248.

Naef, A. (1912b). Teuthologische Notizen, 2: Die Gattungen der Sepioliden. Zool. Cher Anzeiger. 39, 244-248.

Naef, A. (1912c). Teuthologische Notizen. 7. Zur Morphologie und Systematik der Sepiola- und Sepietta-Arten. Zool. Anz. 40, 78-85.

Naef, A. (1912d). Teuthologische Notizen. 3. Die Arten der Gattungen Sepiola und Sepietta. Zool. Anz. 39, 262-271.
Naef, A. (1916). Ueber neue Sepioliden aus dem Golf von Neapel. Pub. Della Stazione Zool. Napoli 1, 1-10.

Nateewathana, A. (1997). The Sepiolidae (Cephalopoda) of the Andaman Sea, Thailand, with description of Euprymna hyllebergi sp. nov. Publ. Phuket Mar. Biol. Cent. 17, 465-481.

Nigmatullin, C. M., Sabirov, R. M., and Zalygalin, V. P. (2003). Ontogenetic aspects of morphology, size, structure and production of spermatophores in ommastrephid squids: an overview. Berliner Paläobiol. Abh. 3, 225-240.

Nishiguchi, M. K., Lopez, J. E., and Boletzky, S. V. (2004). Enlightenment of old ideas from new investigations: more questions regarding the evolution of bacteriogenic light organs in squids. Evol. Dev. 6, 41-49. doi: 10.1111/j.1525-142X.2004.04009.x

Nishiguchi, M. K., Ruby, E. G., and McFall-Ngai, M. J. (1998). Competitive dominance among strains of luminous bacteria provides an unusual form of evidence for parallel evolution in sepiolid squid-Vibrio symbioses. Appl. Environ. Microbiol. 64, 3209-3213. doi: 10.1128/AEM.64.9.3209-3213.1998

Olivar, M. P., Hulley, P. A., Castellón, A., Emelianov, M., López, C., Tuset, V. M., et al. (2017). Mesopelagic fishes across the tropical and equatorial Atlantic: biogeographical and vertical patterns. Prog. Oceanogr. 151, 116-137. doi: 10.1016/j.pocean.2016.12.001

Olmos-Pérez, L., Pierce, G. J., Roura, A., and González, Á. F. (2018a). Barcoding and morphometry to identify and assess genetic population differentiation and size variability in loliginid squid paralarvae from NE Atlantic (Spain). Mar. Biol. 165:136. doi: 10.1007/s00227-018-3387-y

Olmos-Pérez, L., Roura, A., Pierce, G. J., and González, Á. F. (2018b). Sepiolid paralarval diversity in a regional upwelling area of the NE Atlantic. Hydrobiologia 808, 57-70. doi: 10.1007/s10750-017-3186-3

Orsi Relini, L., and Massi, D. (1991). The butterfly squid Stoloteuthis leucoptera in the Mediterranean. J. Mar. Biol. Assoc. U.K. 71, 47-51. doi: 10.1017/S0025315400037383

Orsi-Relini, L. (1995). Notes on midwater collections of Heteroteuthis dispar (Cephalopoda, Sepiolidae). Bull. Inst. Océanogr. 16, 63-72.

Pascual, M., Rives, B., Schunter, C., and Macpherson, E. (2017). Impact of life history traits on gene flow: a multispecies systematic review across oceanographic barriers in the Mediterranean Sea. PLoS ONE 12:e0176419. doi: 10.1371/journal.pone.0176419

Pfeffer, G. (1884). Die Cephalopoden des Hamburger Naturhistorischen Museums. Abhandlungen Gebiete Naturwissenschaften Hamburg 8, 1-30.

Pons, J., Barraclough, T. G., Gómez-Zurita, J., Cardoso, A., Duran, D. P., Hazell, S., et al. (2006). Sequence-based species delimitation for the DNA taxonomy of undescribed insects. Syst. Biol. 55, 595-609. doi: 10.1080/10635150600852011

Puillandre, N., Lambert, A., Brouillet, S., and Achaz, G. (2012). ABGD, automatic barcode gap discovery for primary species delimitation. Mol. Ecol. 21, 1864-1877. doi: 10.1111/j.1365-294X.2011.05239.x

Quetglas, A., Ordines, F., González, M., Zaragoza, N., Mallol, S., Valls, M., et al. (2013). Uncommon pelagic and deep-sea cephalopods in the Mediterranean: new data and literature review. Mediterr. Mar. Sci. 14, 69-85. doi: $10.12681 / \mathrm{mms} .320$

Rambaut, A., and Drummond, A. J. (2003-2009) Tracer: MCMC Trace Analysis Tool. Version 1.10.4, 2003-2009. Available online at: http://tree.bio.ed.ac.uk/ software/tracer/ (accessed December 15, 2020).

Rambaut, A. (2006-2009) FigTree: Tree Figure Drawing Tool. Version 1.4.4, 2006-2009. Available online at: http://tree.bio.ed.ac.uk/software/figtree/ (accessed December 15, 2020).

Reid, A., and Jereb, P. (2005). "Family Sepiolidae," in Cephalopods of the World. An Annotated and Illustrated Catalogue of Species Known to Date. Vol. 1, eds P. Jereb and C. F. E. Roper (Rome: FAO Species Catalogue for Fishery Purposes), 153-203.

Robles, R., Schubart, C. D., Conde, J. E., Carmona-Suárez, C., Alvarez, F., Villalobos, J. L., et al. (2007). Molecular phylogeny of the American Callinectes Stimpson, 1860 (Brachyura: Portunidae), based on two partial mitochondrial genes. Mar. Biol. 150, 1265-1274. doi: 10.1007/s00227-0060437-7

Robson, G. C. (1924). Preliminary report on the Cephalopoda (Decapoda) procured by the S.S. "Pickle." Rep. Fish. Mar. Biol. Surv. Union S. Afr. 3, 1-14.

Roper, C. F. E., and Voss, G. L. (1983). Guidelines for taxonomic descriptions of cephalopod species. Mem. Mus. Vic. 44, 49-63. doi: 10.24199/j.mmv.1983.44.03 
Rosa, R., Pissarra, V., Borges, F. O., Xavier, J., Gleadall, I., Golikov, A., et al. (2019). Global patterns of species richness in coastal cephalopods. Front. Mar. Sci. 7:469. doi: $10.3389 /$ fmars. 2019.00469

Roux, C., Fraïsse, C., Romiguier, J., Anciaux, Y., Galtier, N., and Bierne, N. (2016). Shedding light on the grey zone of speciation along a continuum of genomic divergence. PLoS Biol. 14:e2000234. doi: 10.1371/journal.pbio.2000234

Rüppell, E. (1844). Intorno ad alcuni cefalopodi del mare di Messina: lettera del Dr Eduardo Rüppell di Frankfort sul Meno al Prof. Anastasio Cocco. Giornale Gabinetto Letterario Messina 5, 129-135.

Sanchez, G., Jolly, J., Reid, A., Sugimoto, C., Azama, C., Marlétaz, F., et al. (2019). New bobtail squid (Sepiolidae: Sepiolinae) from the Ryukyu islands revealed by molecular and morphological analysis. Commun. Biol. 2:465. doi: 10.1038/s42003-019-0661-6

Sánchez, P., Belcari, P., and Sartor, P. (1998). Composition and spatial distribution of cephalopods in two north-western Mediterranean areas. S. Afr. J. Mar. Sci. 20, 17-24. doi: 10.2989/025776198784126584

Sasaki, M. (1918). On Inioteuthis inioteuthis (Naef) and Sepiola birostrata n. sp. Dobutsugaku Zasshi 30, 235-236.

Sasaki, M. (1929). A monograph of the Dibranchiate Cephalopods of the Japanese and Adjacent Waters. J. Coll. Agric. Hokkaido Imp. Univ. 20, 1-357.

Steenstrup, J. (1881). Sepiadarium og Idiosepius to nye Slaegter af Sepiernes Familie, med Bemaerkninger om de to beslaegtede Former Sepiolidea D’Orb. og Spirula Lmk. Danske Videnskabernes Selskabs Skrifter, 6 Raekke. Naturvidenskabelig Mathematisk 1, 211-242.

Steenstrup, J. (1887). Notae Teuthologicae, 6. Species generis Sepiolae Maris Mediterranei. Oversigt Kongelige Danske Videnskabernes Selskabs Forhandlinger $1887,47-66$

Strugnell, J., Norman, M., Drummond, A. J., and Cooper, A. (2004). Neotenous origins for pelagic octopuses. Curr. Biol. 14, R300-R301. doi: 10.1016/j.cub.2004.03.048

Taite, M., Vecchione, M., Fennell, S., and Allcock, A. L. (2020). Paralarval and juvenile cephalopods within warm-core eddies in the North Atlantic. Bull. Mar. Sci. 96, 235-261. doi: 10.5343/bms.2019.0042

Tamura, K., Stecher, G., Peterson, D., Filipski, A., and Kumar, S. (2013). MEGA6: molecular evolutionary genetics analysis version 6.0. Mol. Biol. Evol. 30, 2725-2729. doi: 10.1093/molbev/mst197

Trifinopoulos, J., Nguyen, L.-T., Haeseler, A. V., and Quang Minh, B. (2016). W-IQ-TREE: a fast online phylogenetic tool for maximum likelihood analysis. Nucleic Acids Res. 44, W232-W235. doi: 10.1093/nar/ gkw256

Vecchione, M., and Young, R. E. (2007). Heteroteuthis dispar (Ruppell 1844). Version 26 December 2007 (Under Construction). Available online at: http:// tolweb.org/Heteroteuthis_dispar/20054/2007.12.26 (accessed November 18, 2020).

Vecchione, M., and Young, R. E. (2013). Stoloteuthis leucoptera (Verrill 1878). Version 03 November 2013. Available online at: http://tolweb.org/Stoloteuthis_ leucoptera/27774/2013.11.03 (accessed November 18 2020).
Verrill, A. E. (1878). Notice of recent addition to the Marine Fauna of the eastern coast of North America. Am. J. Sci. 16, 371-378. doi: 10.2475/ajs.s3-16.95.371

Verrill, A. E. (1880). Notice of the remarkable marine fauna occupying the outer banks off the southern coast of New England. Am. J. Sci. 20, 390-403. doi: 10.2475/ajs.s3-20.119.390

Verrill, A. E. (1881). The Cephalopods of the Northeastern Coast of America. Part II. The smaller cephalopods, including the "squids" and the octopi, with other allied forms. Trans. Connecticut Acad. Sci. 5, 259-446. doi: 10.5962/bhl.title.11201

Villanueva, R. (1995). Distribution and abundance of bathyal sepiolids (Mollusca: Cephalopoda) in the northwestern Mediterranean. Bull. Inst. Océanogr. $16,19-26$.

Villanueva, R., Laptikhovsky, V. V., Piertney, S. B., Fernández-Álvarez, F. Á., Collins, M. A., Ablett, J. D., et al. (2020). Extended pelagic life in a bathybenthic octopus. Front. Mar. Sci. 7:561125. doi: 10.3389/fmars.2020.561125

Villanueva, R., and Sánchez, P. (1993). Cephalopods of the Benguela Current off Namibia: new additions and considerations on the genus Lycoteuthis. J. Nat. His. 27, 15-46. doi: 10.1080/00222939300770021

Villanueva, R., Vidal, E. A. G., Fernández-Álvarez, F. Á., and Nabhitabhata, J. (2016). Early mode of life and hatchling size in cephalopod molluscs: influence on the species distributional ranges. PLOS ONE, 11:e0165334. doi: 10.1371/journal.pone.0165334

Volpi, C., Borri, M., and Zucchi, A. (1995). Notes on the family Sepiolidae (Mollusca, Cephalopoda) off the Northern Tuscany coast. Bull. Inst. Océanogr. $16,27-34$.

Würtz, M., Matricardi, G., and Repetto, N. (1995). Sepiolidae (Mollusca, Cephalopoda) from the lower Tyrrhenian Sea, Central Mediterranean. Bull. Inst. océanogr. 16, 35-39.

Zaragoza, N., Quetglas, A., Hidalgo, M., Álvarez-Berastegui, D., Balbín, R., and Alemany, F. (2015). Effects of contrasting oceanographic conditions on the spatiotemporal distribution of Mediterranean cephalopod paralarvae. Hydrobiologia 749, 1-14. doi: 10.1007/s10750-014-2132-x

Zhang, J., Kapli, P., Pavlidis, P., and Stamatakis, A. (2013). A general species delimitation method with applications to phylogenetic placements. Bioinformatics 29, 2869-2876. doi: 10.1093/bioinformatics/btt499

Conflict of Interest: The authors declare that the research was conducted in the absence of any commercial or financial relationships that could be construed as a potential conflict of interest.

Copyright (๑) 2021 Fernández-Álvarez, Sánchez and Villanueva. This is an openaccess article distributed under the terms of the Creative Commons Attribution License (CC BY). The use, distribution or reproduction in other forums is permitted, provided the original author(s) and the copyright owner(s) are credited and that the original publication in this journal is cited, in accordance with accepted academic practice. No use, distribution or reproduction is permitted which does not comply with these terms. 